\title{
Chemistry of 2-amino-4-oxo-4H-1-benzopyran-3-carboxaldehydes
}

\author{
Chandra Kanta Ghosh, ${ }^{* a}$ Amarnath Chakraborty, \\ and Chandrakanta Bandyopadhyay \\ a Organic Chemistry Laboratory, Department of Biochemistry, Calcutta University, \\ Kolkata 700 019, India \\ ${ }^{b}$ Department of Basic Sciences and Humanities, Institute of Engineering \& Management, \\ Salt Lake Electronics Complex, Sector-5, Kolkata 700 091, India \\ ${ }^{c}$ Department of Chemistry, R. K. Mission Vivekananda Centenary College, \\ Rahara, Kolkata 700 118, India \\ E-mail: ghosh.chandrakanta@gmail.com; amarnath.chemistry@gmail.com; \\ kantachandra@rediffmail.com
}

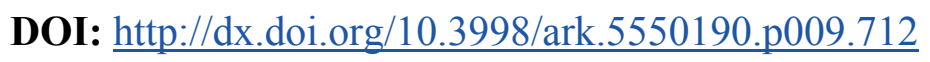

\begin{abstract}
The review article gives a comprehensive survey of the synthesis and chemistry of 2-amino-4oxo-4H-1-benzopyran-3-carboxaldehydes, covering the literature to March, 2016.

Keywords: 1-Benzopyran-4-ones, Michael additions, Friedländer annulations, intramolecular cycloadditions, rearrangements, metal complex formation
\end{abstract}

\section{Table of Contents}

1. Introduction

2. Synthesis

3. Reduction

4. Reactions with Nitrogenous Nucleophiles

4.1. Reaction with amines

4.1.1. Reaction with aliphatic amines

4.1.2. Reaction with aromatic amines

4.2. Reaction with hydrazine

4.3. Reaction with hydroxylamine

4.4. Reaction with amidines and thioamides

5. Reaction with Activated Alkynes and Alkenes

6. Friedländer Annulation 
6.1. Annulation with active methylene compounds

6.2. Annulation with aryl and hetaryl methyl ketones

6.3. Annulation with alkyl methyl ketones

6.4. Annulation with enols and enamines

7. Amine-Formalin Mediated Conversion of 2-(N-Alkyl/aryl-amino)-3-formylchromones

8. Conversion of 2-Arylamino-3-formylchromone into [1]Benzopyrano[2,3- $b$ ] quinoline

9. Reactions of 2-( $N$-Alkenyl- $N$-aryl)-3-formylchromones

10. Reactions of 2-(N-Alkynyl- $N$-aryl)-3-formylchromones

11. Conclusion

References

\section{Introduction}

2-Amino-4-oxo-4H-1-benzopyran-3-carboxaldehydes (trivial name: 2-amino-3-formylchromones) (1-4) like their 2-unsubstituted analogue 3 -formylchromone (5) ${ }^{1}$ possess an activated endocyclic olefinic bond, three electrophilic centres, namely pyran C-2, aldehydic carbon and endocyclic carbonyl carbon, the last named (C-4) being the least electrophilic. Electrophilicity at their amino substituted C-2 is somewhat reduced due to the positive resonance effect of the amino group and compares well to that at $\mathrm{C}$-2 of 3-formyl-2-methylchromone 8. $^{2}$ Again, the chromones 1-4 through their amino groups can function as nucleophiles as $\mathbf{8}$ does through its 2-methyl group in the presence of an appropriate base. The amino-aldehyde $\mathbf{1}$ in this respect can be regarded as an aza-analogue of the aldehyde 8. Furthermore nucleofugality of the amino groups, particularly secondary and tertiary ones, in the title chromones while behaving as Michael acceptors towards several nucleophiles, may come to the fore. Because of these functionalities (activated olefinic bond, electrophilicity at three centres, and nucleophilicity and nucleofugality of the amino group), the chemistry of the chromones $\mathbf{1 - 4}$ is more varied. The present article is a comprehensive survey of the chemistry and applications of the chromones 1-4, and covers the literature to March, 2016. Patented works on the chromones 1-4 are not covered, and the biological activity of the compounds 1-4 and products obtainable therefrom are less emphasized. Most of the reactions described here for the chromones 1-4 generally do not affect any alkyl, alkoxy and halogeno substituents if they are present in the benzene or fused aromatic or heteroaromatic ring in these chromones. Unless specified otherwise, the chromones $\mathbf{2} \mathbf{b}\left(\mathrm{R}^{1}=\mathrm{H}\right.$, $\left.\mathrm{R}^{2}=\mathrm{Ph}\right), \mathbf{3 a}\left(\mathrm{R}^{1}=\mathrm{Me}, \mathrm{R}^{2}=\mathrm{Ph}\right)$ and $\mathbf{4}\left(\mathrm{R}^{1}=\mathrm{R}^{2}=\mathrm{Me}\right)$ are simply written throughout this article as $\mathbf{2 , 3}$ and $\mathbf{4}$, respectively. 
<smiles>[R]N([R])c1oc2ccccc2c(=O)c1C=O</smiles>

$1-4$

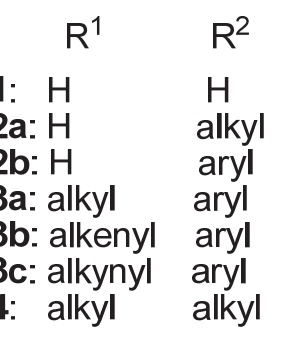<smiles>[X]c1coc2ccccc2c1=O</smiles>

5: $\mathrm{X}=\mathrm{CHO}$

6: $\mathrm{X}=\mathrm{CH}=\mathrm{NOH}$

7: $\mathrm{X}=\mathrm{CN}$<smiles>Cc1oc2ccccc2c(=O)c1C=O</smiles>

8

\section{Synthesis}

In its reaction with a nucleophile of general form $\mathrm{YH}_{2}$ the nitrile 7 behaves as a 'chemical equivalent' of the amine 1, provided the nucleophile undergoes Michael addition to the activated endocyclic olefinic bond of 7 with concomitant pyran ring opening (to $\mathbf{A}$ ) and recyclization (through B) to yield $\mathbf{C}$ obtainable by condensation of $\mathbf{1}$ with $\mathrm{YH}_{2}$ (Scheme 1). The compound $\mathbf{C}$ may, however, undergo further transformation (vide infra), depending on the nature of the $\mathrm{Y}$ grouping. So the nitrile is indeed the preferred starting material for the synthesis of 2-amino-3formylchromone 1. The formation of $\mathbf{1}$ by treating 3-cyanochromone $\mathbf{7}$, derived from the aldehyde 5 via the oxime 6, with an aqueous ethanolic solution (2\%) of sodium hydroxide at $70{ }^{\circ} \mathrm{C},{ }^{3}$ with a small amount of morpholine in $\mathrm{DMF}-\mathrm{H}_{2} \mathrm{O}$ at $60^{\circ} \mathrm{C}$, ${ }^{4,5}$ with ethylenediamine in aqueous ethanol $(1: 1)$ under reflux, ${ }^{6}$ or by stirring a solution of 3-cyanochromone in $\mathrm{CH}_{2} \mathrm{Cl}_{2}$ with alumina at ambient temperature ${ }^{7}$ has been reported. The aldehyde $\mathbf{1}$ can also be prepared by warming an ethanolic solution of the aldoxime 6 with aqueous $\mathrm{NaOH}^{3}$ Ethylenediamine-induced self-condensation of $\mathbf{6}$ as well as 7 gives the fused 1,5-diazocine $\mathbf{9}$ which is hydrolysed in boiling aqueous acetic acid to the amino-aldehyde $1 .{ }^{8}$ Heating the nitrile (1 equiv) with ethylenediamine ( 0.5 equiv) in ethanol for $10 \mathrm{~min}$ is reported to produce the bis-imine 10, which, depending on the time of reflux in $\mathrm{AcOH}$, affords the amine $\mathbf{1}$ or the benzopyranopyrimidine $11 .{ }^{9}$ All these methods for the conversion of the nitrile 7 to the aldehyde $\mathbf{1}$ are fully discussed in a review article. $^{10}$

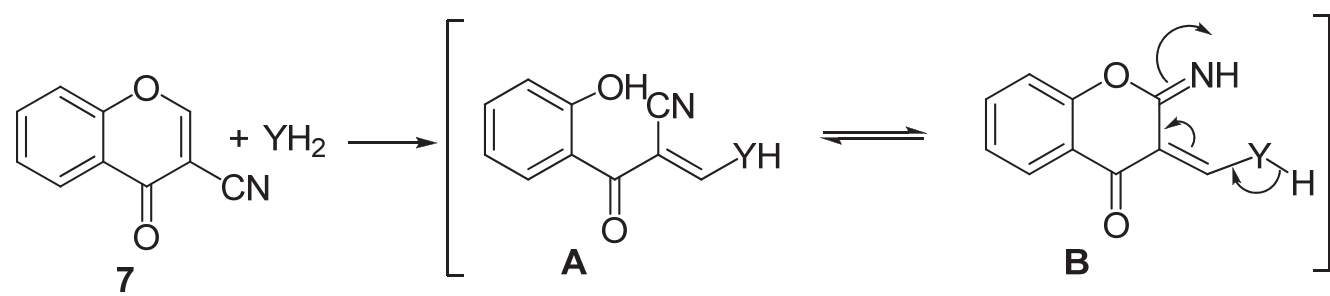

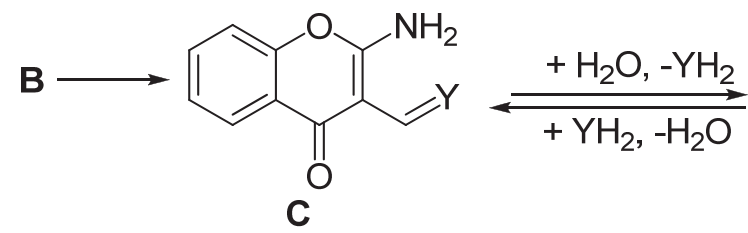<smiles>Nc1oc2ccccc2c(=O)c1C=O</smiles>

Scheme 1 
<smiles>O=c1c2ccccc2oc2ncc3c(=O)c4oc5ccccc5oc4[nH]c3ncc12</smiles><smiles>Nc1oc2ccccc2c(=O)c1C=NCCN=Cc1c(N)oc2ccccc2c1=O</smiles>

10<smiles></smiles>

$C$-(4-Oxo-4H-1-benzopyran-3-yl)- $N$-phenylnitrone 12, obtainable from the aldehyde 5 and phenylhydroxylamine, undergoes facile rearrangement on refluxing in benzene yielding 2anilino-3-formylchromone $\mathbf{2}(70 \%)$ and 3-(phenylaminomethylene)chroman-2,4-dione $\mathbf{1 3}$ (E/Zmixture, 25\%) (Scheme 2). ${ }^{11}$ The intermediate $\mathbf{D}$ arising from an initial 1,5-electrocyclization of the nitrone 12 undergoes a 1,5-H shift giving through $\mathbf{E}$ the chromandione $\mathbf{1 3}$ (path $a$ ). An alternative rearrangement of $\mathbf{D}$ involving its conversion to the pyran ring opened intermediate $\mathbf{F}$ followed by recyclization $(\rightarrow \mathbf{G}$ ) and a 1,5-H shift yields the 2 -anilinochromone 2 (path $b$ ). It is pertinent to mention here that a solution of the aldehyde $\mathbf{5}$ and aniline in benzene containing K10 montmorillonite on reflux with stirring affords an $E / Z$-mixture of 13 in $\sim 45 \%$ yield. $^{12}$
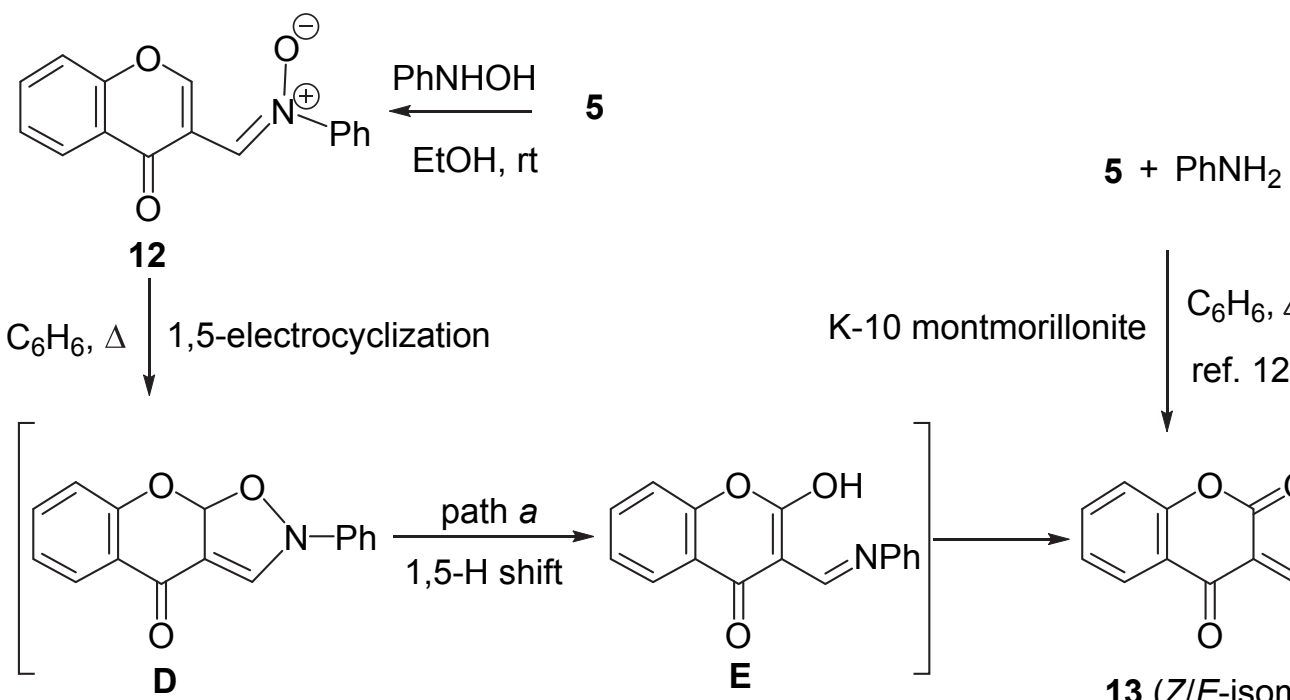

path $b \downarrow$<smiles>O=C(c1cn(-c2ccccc2)[n+](-c2ccccc2)c1)c1ccccc1[O-]</smiles><smiles>O=C1C2=CON(c3ccccc3)C2Oc2ccccc21</smiles><smiles></smiles>

\section{Scheme 2}


Ghosh and Bandyopadhyay ${ }^{13}$ have shown that the rearrangement of the nitrone 15, prepared by reacting the aldehyde 5 with nitro -alkane or -arene $\mathbf{1 4}$ and zinc in $\mathrm{EtOH}$ in the presence of $\mathrm{AcOH}$, to either the aldehyde $2\left(\mathrm{R}^{1}=\mathrm{H}, \mathrm{R}^{2}=\right.$ alkyl or aryl) or/and dione 16, is a solventdependent process. The nitrone 15a whether refluxed in a protic solvent (MeOH or EtOH) or an aprotic solvent (MeCOMe, $\mathrm{MeCN}$ ) gives 2a exclusively. Arylnitrone $\mathbf{1 5 b}$ fails to rearrange in boiling $\mathrm{MeOH}$ but readily rearranges to $\mathbf{2 b}$ when heated under reflux in ethanol or acetonitrile. Both the nitrones $\mathbf{1 5 a}, \mathbf{b}$ when stirred in $\mathrm{AcOH}$ at room temperature rearrange to $\mathbf{2 a , b}$. In contrast, each of the nitrones $\mathbf{1 5}$ in refluxing toluene or xylene gives the dione $\mathbf{1 6}$ (an E/Zmixture) as the major product (60-80\%), together with the aldehyde 2 (10-20\%). It seems clear that a protic solvent has little effect on the rearrangement, but its outcome depends on the polarity of the solvent and also on the reaction temperature.<smiles>[R]NC=C1C(=O)Oc2ccccc2C1=O</smiles>

$$
\text { For 2,14-16 } \begin{aligned}
\mathbf{a}: \mathrm{R}^{2}=\mathrm{Me}, \mathrm{Et} \\
\\
\mathbf{b}: \mathrm{R}^{2}=\mathrm{Ph}, \mathrm{C}_{6} \mathrm{H}_{4} \mathrm{Me}-4
\end{aligned}
$$

A one-pot synthesis of the aminochromone 2 by $\mathrm{Zn}$-aq. $\mathrm{NH}_{4} \mathrm{Cl}$ mediated reaction of the aldehyde 5 and nitro compound $\mathbf{1 4}$ in THF has been achieved. ${ }^{14}$ The reaction mixture of 5 and 14a when stirred for $7 \mathrm{~h}$ at room temperature affords 2 -( $N$-alkylamino)chromone $\mathbf{2 a}(\sim 45 \%)$, $\mathrm{MeNO}_{2}$ additionally producing a small amount of the Knoevenagel condensation product, the 3-(2-nitrovinylchromone). A stirred reaction mixture of 5 and nitroarene $\mathbf{1 4 b}$ at room temperature for $4 \mathrm{~h}$ shows the formation of the nitrone $\mathbf{1 5 b}$ along with $\mathbf{2 b}$. The same mixture on stirring for $4 \mathrm{~h}$ at $60{ }^{\circ} \mathrm{C}$ produces $\mathbf{2 b}$ in $55-60 \%$ yield.<smiles>[R]c1ccc2oc(N([R])CC)cc(=O)c2c1[R]</smiles>

$17: \mathrm{R}^{1}=\mathrm{R}^{2}=\mathrm{H}$;

18<smiles>[R]c1ccc2oc(N([R])CCCC)c(C)c(=O)c2c1[R]</smiles>

19

For 18 and $19: \mathrm{R}^{1} \mathrm{R}^{2}=\mathrm{CH}=\mathrm{CH}-\mathrm{CH}=\mathrm{CH}$

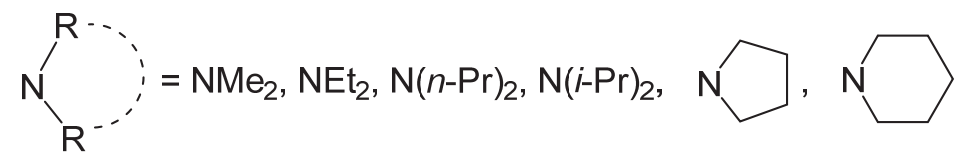


Preparation of 2-( $N$-alkyl- $N$-arylamino)-3-formylchromone 3a by $N$-alkylation of 2- $N$ arylaminochromone $\mathbf{2 b}$ with alkyl halide is discussed later while describing its reactions. 2-(Dialkylamino)chromones $17(\mathrm{R}=\mathrm{Me}, \mathrm{Et})$ have been formylated at their 3-position with DMF-POCl ${ }_{3}$ or $\mathrm{Cl}_{2} \mathrm{CHOMe}$ in the presence of $\mathrm{TiCl}_{4}$ to afford $4\left(\mathrm{R}^{1}=\mathrm{R}^{2}=\mathrm{Me}\right.$ or Et $){ }^{15} \mathrm{DMF}-$ $\mathrm{POCl}_{3}$ formylates the naphthopyranone $\mathbf{1 8}$ to 3 -formylpyranone $19 .{ }^{16}$

\section{Reduction}

The chromone 20 when refluxed with $\mathrm{Zn}$ in $\mathrm{AcOH}$ gives depending on the nature of the $\mathrm{NR}^{1} \mathrm{R}^{2}$ group either 2-arylamino-3-methylchromone $\mathbf{2 1}$ or 3-methyl-4-hydroxycoumarin $\mathbf{2 2}$ as shown in Scheme $3 .^{17}$

A.
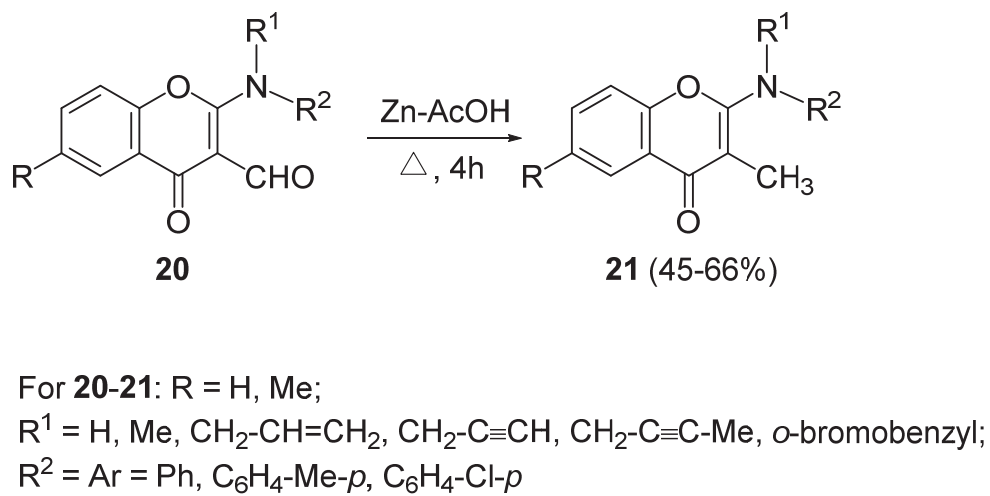

B.

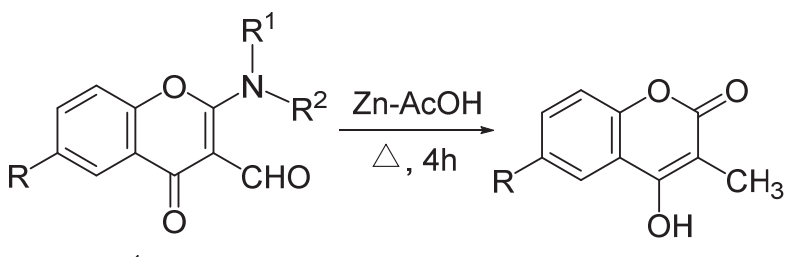

20: $\mathrm{R}, \mathrm{R}^{1}=\mathrm{H}, \mathrm{Me}$; $\mathrm{R}^{2}=\mathrm{H}, \mathrm{Me}, \mathrm{Et}$

$22(44-52 \%)$

\section{Scheme 3}

\section{Reactions with Nitrogenous Nucleophiles}

\subsection{Reaction with amines}

4.1.1. Reaction with aliphatic amines. 2-Aminochromone-3-carbaldehyde 1 behaves as a heteroaromatic aldehyde towards an aliphatic primary amine, the resultant Schiff base functioning as a $N, N$-donor heterocyclic chelator for several metal ions. As for example, Schiff base ligand 23 ( $\equiv \mathrm{L}$ ) derived from the condensation of aldehyde 1 with $(R)$-2-amino-2-phenyl- 
ethanol forms a pentacoordinated $\mathrm{Cu}(\mathrm{II})$ complex 24 with $\mathrm{Cu}\left(\mathrm{NO}_{3}\right)_{2}$ and a tetracoordinated $\mathrm{Zn}(\mathrm{II})$ complex 25 with $\mathrm{Zn}\left(\mathrm{NO}_{3}\right)_{2}{ }^{18}$<smiles>Nc1oc2ccccc2c(=O)c1C=NC(CO)c1ccccc1</smiles>

23
$\left[\mathrm{CuL}_{2}\left(\mathrm{H}_{2} \mathrm{O}\right)\right]\left(\mathrm{NO}_{3}\right)_{2} \quad\left[\mathrm{ZnL}_{2}\right]\left(\mathrm{NO}_{3}\right)_{2}$

24
25

Chiral Schiff bases 26 ( $\equiv L^{\prime}$ ) derived from aldehyde 1 and each enantiomer of 2aminopropan-1-ol function as tridentate ligands coordinating through their amino nitrogen, imino nitrogen and hydroxy oxygen. These ligands form with copper(II) nitrate and zinc(II) nitrate the pentacoordinated $\mathrm{Cu}$ (II) and tetracoordinated $\mathrm{Zn}$ (II) complexes 27 and 28 respectively. The DNA binding studies of these complexes with calf thymus reveal that both $R-\mathbf{2 7}$ and $S-27$ prefer guanine-cytosine rich region whereas $R-\mathbf{2 8}$ and $S \mathbf{- 2 8}$ prefer adenine-thymine residues in the major groove of DNA, $R-27$ showing better DNA cleavage activity. ${ }^{19}$ In its reaction with trans$\mathrm{RuCl}_{2}\left(\mathrm{PPh}_{3}\right)_{2}$ in refluxing toluene under an open atmosphere to form the ruthenium complex 30, the Schiff base 29 behaves differently from the previous two imines 23 and 26; here the $\mathrm{NH}_{2}$ group at the pyran 2-position functions as a vinylogous amide and consequently this amino nitrogen is covalently (not coordinately as in $\mathbf{2 3}$ and 26) bonded to the tripositive ruthenium arising from air oxidation of $\mathrm{Ru}(\mathrm{II}) .^{20}$<smiles>CC(C)/N=C/c1c(N)oc2ccccc2c1=O</smiles>

$26 \equiv L^{\prime}$
$\left[\mathrm{CuL}^{\prime}\left(\mathrm{H}_{2} \mathrm{O}\right)\left(\mathrm{NO}_{3}\right)\right] \mathrm{NO}_{3}$

27

$\left[\mathrm{ZnL}^{\prime}\left(\mathrm{NO}_{3}\right)\right] \mathrm{NO}_{3}$

28<smiles>C#CC(N=Cc1c(N)oc2ccccc2c1=O)C(F)F</smiles>

$\left[\mathrm{Ru}{ }^{\mathrm{III}} \mathrm{Cl}(\mathrm{HChPr})\left(\mathrm{PPh}_{3}\right)\right]_{2}(u-\mathrm{Cl})_{2}$

30

Pictet-Spengler reaction of 5-hydroxydopamine hydrochloride $\mathbf{3 1}$ with the aldehyde $\mathbf{1}$ gives 1-(1-benzopyran-3-yl)isoquinoline derivative $32 .^{21}$<smiles>NCCc1cc(O)c(O)c(O)c1</smiles>

31<smiles>Nc1oc2ccccc2c(=O)c1C1NCCc2cc(O)c(O)c(O)c21</smiles>

32

2-( $N, N$-Disubstituted amino)chromone-3-aldehydes $\mathbf{3}$ and $\mathbf{4}$ behave differently from their $N$ unsubstituted analogue 1 towards an aliphatic primary amine or diamine. A primary amine 
instead of initially condensing with the aldehyde function of $\mathbf{3}$ and $\mathbf{4}$ undergoes an aza-Michael addition to their $\alpha, \beta$-unsaturated carbonyl moiety with concomitant expulsion of the nucleofugal disubstituted amine; the net result is thus an amine exchange reaction. ${ }^{22-28}$ As for example, in 8-isopropyl-5-methyl-2-(dimethylamino)chromone-3-aldehyde on treatment with tri- or pentamethylenediamine the dimethylamino group is replaced by $\mathrm{NH}\left(\mathrm{CH}_{2}\right)_{\mathrm{n}} \mathrm{NH}_{2}(\mathrm{n}=3 \text { or } 5)^{22,23}$ Reactions involving equimolar amounts of $\mathbf{1 9}$ and $n$-propanamine in refluxing toluene gives the amino-aldehyde $\mathbf{3 3}$ that can react with a second molecule of $n$-propanamine giving the imine 34. ${ }^{24}$ Similarly in refluxing $\mathrm{MeCN}_{-} \mathrm{H}_{2} \mathrm{O}$ (65:25) the aminochromone 3 gives 35 with one equivalent of a primary aliphatic or aromatic amine $\mathrm{RNH}_{2}$ but 36 with two equivalents of the same amine. ${ }^{25}$ A similar amine exchange reaction in the aminochromone $\mathbf{3 b}$ is presented in Section 9.
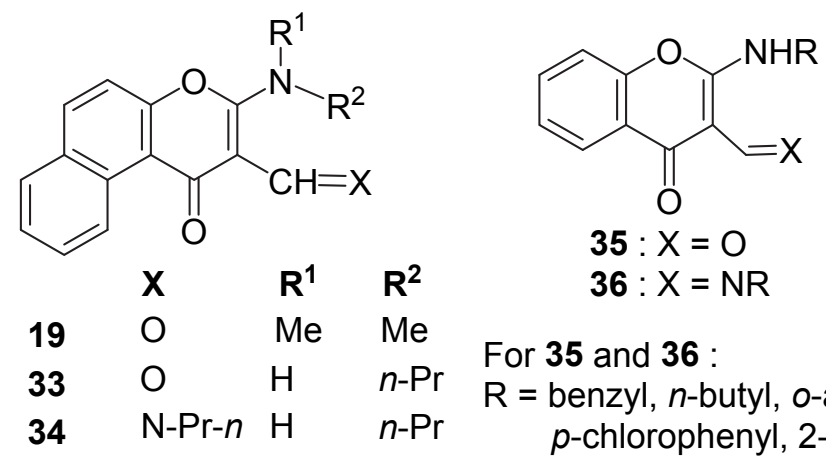
For 35 and 36 :
$\mathrm{R}=$ benzyl, $n$-butyl, o-anisyl, $p$-tolyl, p-chlorophenyl, 2-naphthyl

Sottofattori et al. ${ }^{24}$ have obtained 2-methylenetetrahydropyrimidine 40 by reacting the aldehyde 19 with an excess of propane-1,3-diamine 37a in refluxing toluene and suggested a mechanism for the reaction as depicted in Scheme 4, path $a$. The intermediate $\mathbf{3 8}$ arising from 19 and 37a through an amine exchange and subsequent intramolecular Michael addition condenses with a second molecule of $\mathbf{3 7 a}$ (path $a$ ); the resultant intermediate $\mathbf{3 9}$ undergoes fragmentation to 40 and 3,4,5,6-tetrahydropyrimidine. The present authors opine that nitrogen bonded hydrogen of the hexahydropyrimidine moiety in $\mathbf{3 9}$ is not at all acidic and so it is quite unlikely to trigger under base catalysis the suggested fragmentation (path $a$ ). Contrarily, the secondary amino group of the intermediate $\mathbf{3 8}$ is evidently more nucleophilic than the primary amino group in $\mathbf{3 7 a}$; hence the base-catalyzed deformylative pyran ring opening of $\mathbf{3 8}$ to $\mathbf{4 0}$ is more facile, the intermediate 38 itself functioning as the catalyst (path $b$ ).

The reaction course for the reported formation of the nitrogen heterocycles $\mathbf{4 2}$ via 41 from the aldehyde $\mathbf{3}$ and diamine $\mathbf{3 7}$ in hot aqueous acetonitrile (80:20) (Scheme 5$)^{26}$ differs from that for the formation of $\mathbf{4 0}$ from the allied aldehyde 19 and 37a (Scheme 4), the reaction conditions most probably influencing the reaction outcome. The possible conversion of $\mathbf{4 2}$ into $\mathbf{4 3}$ was not attempted. 


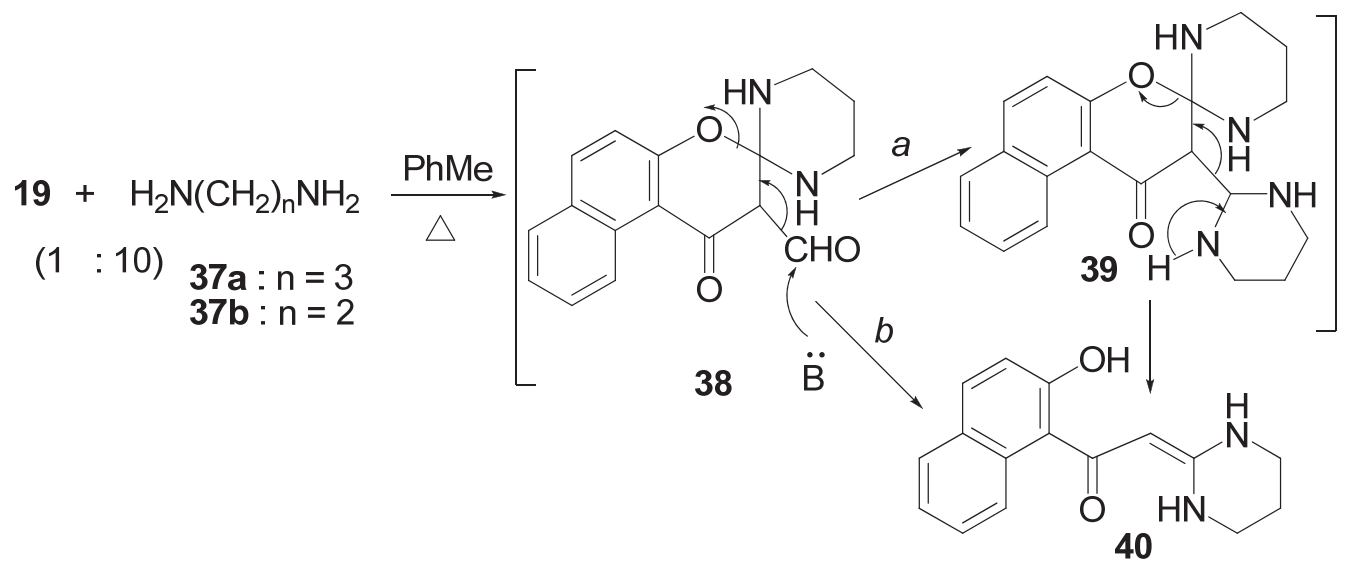

\section{Scheme 4}
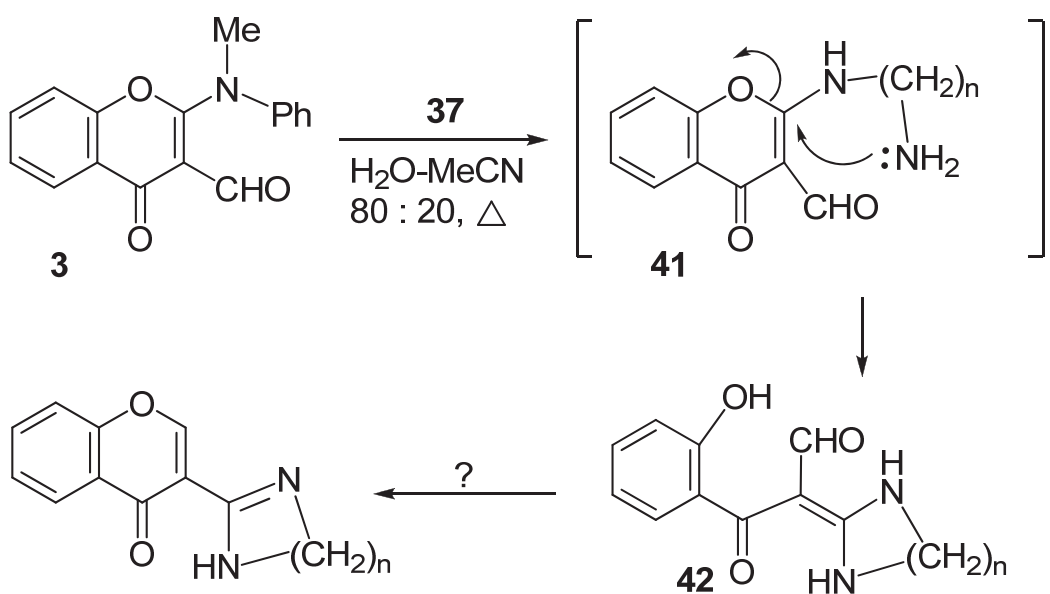<smiles>CC(C(=O)c1ccccc1O)=C1NCCN1</smiles>

43

For $37,41-43: n=3$ or 2

\section{Scheme 5}

When an equivalent amount of the aldehyde $\mathbf{3}$ and $m$-xylylenediamine 44 are refluxed together in $\mathrm{MeCN}$, a [2+2] macrocycle 45 is formed in $96 \%$ yield. $^{27}$<smiles>CC(C)(S)c1cccc(CN=Cc2c(NCc3cccc(CN=Cc4c(NCc5cccc(CN)c5)oc5ccccc5c4=O)c3)oc3ccccc3c2=O)c1</smiles> 
An interesting reaction of the aldehyde 3 with methyl glycinate hydrochloride 46, ultimately yielding through $\mathbf{4 7}$ the pyrrolo[2,3-b][1] benzopyran 48, is depicted in Scheme $6 .{ }^{27}$

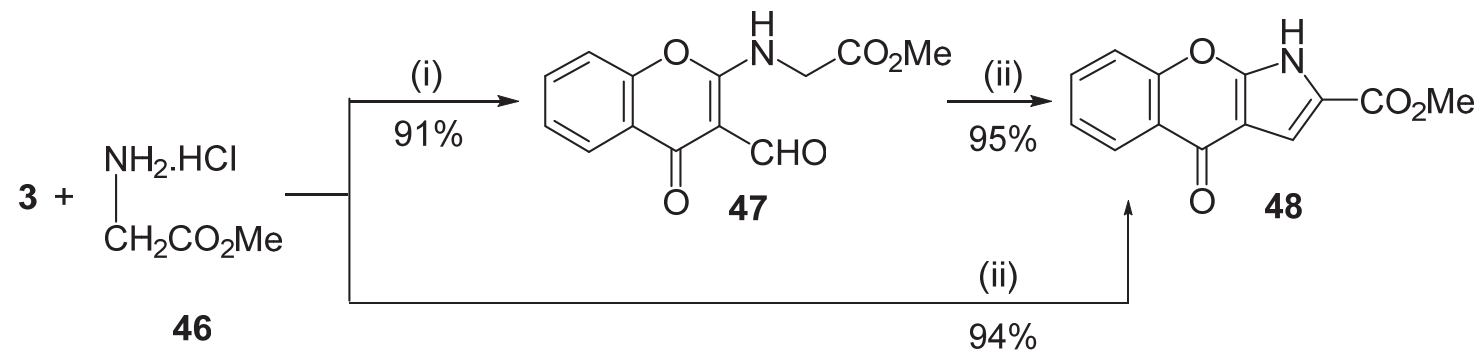

Scheme 6. Reagents and conditions: (i) $\mathrm{H}_{2} \mathrm{O}: \mathrm{MeCN}$ (80:20), $\mathrm{Et}_{3} \mathrm{~N}, \Delta$; (ii) $\mathrm{H}_{2} \mathrm{O}: \mathrm{MeCN}(80: 20$ ), $\mathrm{K}_{2} \mathrm{CO}_{3}, \Delta$.

Many cyclic amines like pyrrolidine, piperidine, morpholine etc. can bring about amine exchange reactions in aminochromone 3. ${ }^{25}$ The 2-aminochromones 49 and $\mathbf{5 0}$ on treatment with the appropriate cyclic amine in refluxing MeCN furnish the respective amine exchange products $\mathbf{5 1}$ and $\mathbf{5 2}$ which are potential topoisomerase inhibitor anticancer agents. ${ }^{28}$<smiles>[X]c1cc2oc(N([Y])c3ccccc3)c(C=O)c(=O)c2cc1[X]</smiles>

$49: \mathrm{X}^{1}=\mathrm{Cl} ; \mathrm{X}^{2}=\mathrm{H}$ $50: \mathrm{X}^{1}=\mathrm{F} ; \mathrm{X}^{2}=\mathrm{Cl}$

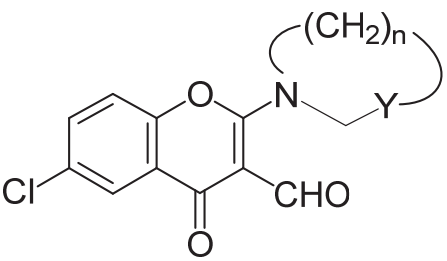

$51: \mathrm{n}=1,2$ $\mathrm{Y}=\mathrm{O}, \mathrm{CH}_{2}, \mathrm{NMe}$<smiles>[Z]C1CCN(c2cc3oc(N4CC[Z]CC4)c(C=O)c(=O)c3cc2F)CC1</smiles>

$52: \mathrm{Z}=\mathrm{O}, \mathrm{CH}_{2}, \mathrm{NMe}$

4.1.2. Reaction with aromatic amines. 2-Methyl-3-iminomethylchromone 53, a Schiff base of the aldehyde 8, gives through its dienamine tautomer 54 with $N$-phenylmaleimide (NPMI) the [4+2]cycloadduct 55. In contrast, 2-amino-3-iminomethylchromone 56 does not tautomerize to $\mathbf{5 6}$ ', the aza-analogue of the diene 54, and hence it fails to undergo a hetero-Diels-Alder reaction with any dienophile. The imine $\mathbf{5 6}$ when heated with either dimethyl acetylenedicarboxylate (DMAD) or NPMI in DMF under reflux simply undergoes self-condensation to the diazocine 9. ${ }^{29}$ 
<smiles>[R]=Nc1c(C)oc2ccccc2c1=O</smiles>

53<smiles>[R]=Nc1c(N)oc2ccccc2c1=O</smiles>

56<smiles>[R]NC=c1c(=C)oc2c(c1=O)C=CC(=C)C=C2</smiles>

54<smiles>[R]NC=C1C(=N)Oc2ccccc2C1=O</smiles>

$56^{\prime}$<smiles>[R]N[C@H]1c2c(oc3ccccc3c2=O)C[C@H]2C(=O)N(c3ccccc3)C(=O)[C@@H]21</smiles>

55

For 53-56' $: \mathrm{R}=\mathrm{C}_{6} \mathrm{H}_{4} \mathrm{Me}-p$

The condensation of the aldehyde 1 with 2-aminoacetophenone and 4-aminoantipyrine 57 in boiling ethanol containing a catalytic amount of $\mathrm{H}_{2} \mathrm{SO}_{4}$ gives the corresponding Schiff bases whereas that with 6-amino-1,3-dimethyluracil-5-carboxaldehyde $\mathbf{5 8}$ gives the doubly fused diazocine 59. ${ }^{30}$<smiles>Cc1c(N)c(=O)n(-c2ccccc2)n1C</smiles>

57<smiles>Cn1c(N)c(C=O)c(=O)n(C)c1=O</smiles>

58<smiles>Cn1c2c(c(=O)n(C)c1=O)C=Nc1oc3ccccc3c(=O)c1C=N2</smiles>

59

3-Iminomethylchromone 61, derived from the aldehyde $\mathbf{1}$ and $o$-phenylenediamine $\mathbf{6 0}$ (Y $=$ $\mathrm{NH}$ ) in refluxing EtOH, transforms on boiling in $\mathrm{AcOH}$ to the benzimidazole 62, the mechanism of this transformation having been duly discussed. ${ }^{31}$ The aminoaldehyde $\mathbf{3}$ and the amine $\mathbf{6 0}$ when refluxed together in $\mathrm{MeCN}-\mathrm{H}_{2} \mathrm{O}$ (80:20) give the tetracycle $\mathbf{6 3} ;{ }^{25,27}$ reaction between 3 and $m$-phenylenediamine under the same conditions gives the pyranoquinoline 64. A [3+3] macrocycle results from refluxing in xylene a mixture of $\mathbf{3}$ and $m$-aminophenol. ${ }^{27}$<smiles>Nc1ccccc1[Tl]</smiles>

60<smiles>Nc1ccccc1/N=C/c1c(N)oc2ccccc2c1=O</smiles>

61<smiles>O=c1c(-c2nc3ccccc3[nH]2)coc2ccccc12</smiles><smiles>[Y]c1ccccc1/N=C/c1c([Y])oc2ccccc2c1=O</smiles>

63<smiles>Nc1ccc2cc3c(=O)c4ccccc4oc3nc2c1</smiles>

$64 \quad$ For 60 and $63: \mathrm{Y}=\mathrm{O}, \mathrm{NH}, \mathrm{S}$ 
A mixture of the aminoaldehyde $19\left(\mathrm{NR}_{2}=\mathrm{NMe}_{2}\right)$ and $o$-phenylenediamine $65(\mathrm{R}=\mathrm{H}, \mathrm{Me}$, $\mathrm{Ph}, p-\mathrm{C}_{6} \mathrm{H}_{4} \mathrm{Cl}$ ) when heated in $\mathrm{AcOH}$ under reflux produces the fused 1,5-diazepine 66 (66$94 \%)$. The reaction of the aforesaid aldehyde with a monosubstituted diamine $65(\mathrm{R} \neq \mathrm{H})$ in refluxing pyridine generally affords 66 in low yield $(\sim 20 \%)$, it being associated with its isomer $67(\sim 8 \%){ }^{32}$<smiles>[R]Nc1cc([R1])c([R])cc1N</smiles>

65<smiles>[R]c1cc2c(cc1[R])N([R])c1oc3ccc4ccccc4c3c(=O)c1C=N2</smiles>

66<smiles></smiles>

For $65-67: \mathrm{R}^{1}=\mathrm{H}, \mathrm{Me}$

\subsection{Reaction with hydrazines}

All the chromone-3-aldehydes 1-4 irrespective of the nature of the amino group at their pyran 2position get derivatized through their aldehyde function by the hydrazide $\mathrm{NH}_{2} \mathrm{NHY}$ to the corresponding hydrazones that may undergo further transformation depending on the nature of their $\mathrm{NR}^{1} \mathrm{R}^{2}$ and NHY groupings. The aldehyde $\mathbf{1}$ with the hydrazine $\mathbf{6 8}$ in boiling ethanol containing a catalytic amount of acetic acid gives the hydrazone 69 that in refluxing DMF is converted through $\mathbf{7 0}$ into the pyranopyrazole 71, also available by heating $\mathbf{1}$ with hydrazine hydrate in DMF under reflux (Scheme 7). ${ }^{30}$ The amine 3 with hydrazine in hot aqueous MeCN $(80: 20)$ also produces $71 .^{25}$<smiles>Nc1oc2ccccc2c(=O)c1C=O</smiles>

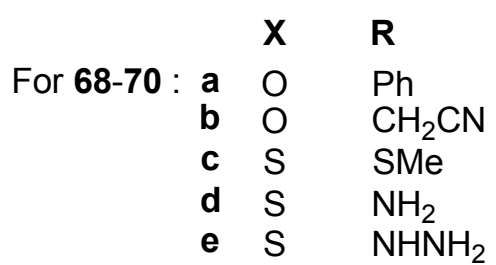

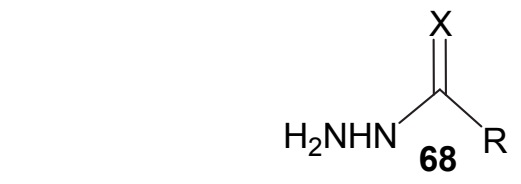

$\mathrm{EtOH}-\mathrm{AcOH}, \triangle$<smiles>[X]C([R])N/N=C/c1c(N)oc2ccccc2c1=O</smiles>

69

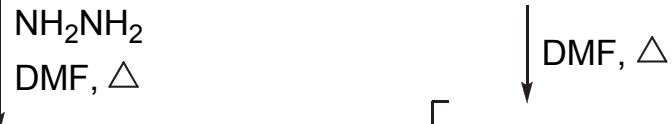<smiles>[X]C(N)Cn1ncc2c(=O)c3ccccc3oc21</smiles>

\section{Scheme 7}


The thiocarbohydrazone 69e in pyridine on being heated with $\mathrm{PhCOCl}, \mathrm{Ac}_{2} \mathrm{O}$ and $\mathrm{CS}_{2}$ gives the triazoles 72, 73 and 74, respectively. ${ }^{30}$ Heterocyclization of the $-\mathrm{NH}-\mathrm{C}(=\mathrm{X}) \mathrm{NHNH}_{2}$ functionality of $69 \mathrm{e}$ with some 1,2-bifunctional electrophiles as $\mathrm{ClCOCOCl}, \mathrm{ClCH}_{2} \mathrm{COCl}$, $\mathrm{PhCOCH}_{2} \mathrm{Br}, \mathrm{BrCH}(\mathrm{CN})_{2}$ and $\mathrm{MeCOCO}_{2} \mathrm{Na}$ leading to the appropriate 1,2,4-triazole derivatives has also been reported. ${ }^{30}$

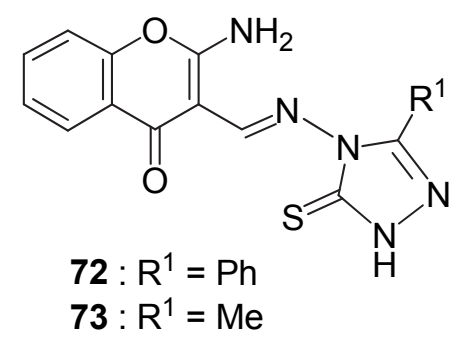<smiles>Nc1oc2ccccc2c(=O)c1/C=N/n1c(=S)[nH][nH]c1=S</smiles>

A mixture of the aldehyde 1 and hydrazine hydrate on being heated with triethylammonium bisulfate $(20 \mathrm{~mol} \%)$ at $120{ }^{\circ} \mathrm{C}$ under solvent free conditions affords the bis-hydrazone $75 .{ }^{33}$ The hydrazone $76(\mathrm{R}=\mathrm{Ph})$, preferentially prepared in quantitative yield by reacting 3cyanochromone 7 with phenylhydrazine in boiling benzene or benzene-triethylamine, on being heated in ethanol containing $20 \% \mathrm{H}_{2} \mathrm{SO}_{4}$, is converted into the pyrazole $77 .{ }^{34}$ The hydrazone 76 ( $\mathrm{R}=$ 2,4-dichlorophenyl, $\mathrm{CO}_{2} \mathrm{Me}, \mathrm{CH}_{2} \mathrm{CH}_{2} \mathrm{OH}$ ) and the bis-hydrazone 78, derived from 1 and benzophenone hydrazone, have been evaluated for cytotoxicity (MTT test) against H2-60 and NALM-6 leukemia cells. ${ }^{35}$ The hydrazone $76\left(\mathrm{R}=\mathrm{CO}_{2} \mathrm{Et}\right)$, obtained from 1 and ethyl carbazate, on heating with ethyl chloroformate gives the carbazate 79 instead of any cyclized product. ${ }^{36}$ The hydrazone 80 obtained by heating the amine 1 with 5,6-diphenyl-1,2,4-triazin-3-ylhydrazine in $\mathrm{CF}_{3} \mathrm{COOH}$ acts as a fluorophore. ${ }^{37}$ Cytotoxicity of the hydrazone $\mathbf{8 1}$ derived from $\mathbf{1}$ and $\mathrm{N}$ amino- $N$ '-hydroxyguanidine against several tumor cells has been studied. ${ }^{38}$ 
<smiles>Nc1oc2ccccc2c(=O)c1/C=N/N=C/c1c(N)oc2ccccc2c1=O</smiles><smiles>[R]NN=Cc1c(N)oc2ccccc2c1=O</smiles><smiles>O=C(c1cnn(-c2ccccc2)c1)c1ccccc1O</smiles><smiles>Nc1oc2ccccc2c(=O)c1/C=N/N=C(\[18O])c1ccccc1</smiles><smiles>CCOC(=O)N/N=C/c1c(NC(=O)OCC)oc2ccccc2c1=O</smiles><smiles>O=c1c(/C=N/Nc2nnc(-c3ccccc3)c(-c3ccccc3)n2)c(NC(F)F)oc2ccccc12</smiles>

80<smiles>N=C(NO)N/N=C/c1c(N)oc2ccccc2c1=O</smiles>

The thiosemicarbazone 69d functions as a tridentate ligand. It is represented as ligand L when an electron lone pair on sulfur of its $-\mathrm{NH}-\mathrm{C}(=\mathrm{S}) \mathrm{NH}_{2}$ grouping is coordinated to the metal but as $\mathrm{L}^{\prime}$ when the sulphide derived from its $-\mathrm{N}=\mathrm{C}\left(\mathrm{NH}_{2}\right) \mathrm{SH}$ grouping is covalently bonded to the metal. The compound 69d gives with copper(II) acetate, sulfate, nitrate, chloride, bromide and perchlorate the $\mathrm{Cu}(\mathrm{II})$ complexes 82 - 87, respectively. $\mathrm{Cu}$ (II) complexes with this thiosemicarbazone ligand and another secondary bidentate ligand as 8-hydroxyquinoline and 1,10-phenanthroline are also reported. ${ }^{39}$

$\mathrm{CuL}^{\prime}\left(\mathrm{H}_{2} \mathrm{O}\right)(\mathrm{MeCOO})$

82

[CuL'Cl].0.5 $\mathrm{H}_{2} \mathrm{O}$

85
$\left[\mathrm{CuL}\left(\mathrm{H}_{2} \mathrm{O}\right)\left(\mathrm{SO}_{4}\right)\right]$

83

$\left[\mathrm{CuL}^{\prime}\left(\mathrm{H}_{2} \mathrm{O}\right)\right] \mathrm{Br}$

86
$\left[\mathrm{CuL}\left(\mathrm{NO}_{3}\right)\right]$

84
$\left[\mathrm{CuL}\left(\mathrm{H}_{2} \mathrm{O}\right)_{3}\right]\left(\mathrm{ClO}_{4}\right)_{2} \cdot 3 \mathrm{H}_{2} \mathrm{O}$

87

Antibacterial activity of the thiosemicarbazone $\mathbf{8 8}$ prepared by treating the appropriate chromone-3-aldehyde with thiosemicarbazide in $\mathrm{MeOH}$ containing $\mathrm{Zn}\left(\mathrm{ClO}_{4}\right)_{2}$ as catalyst at room temperature against E.coli has been assessed. ${ }^{40}$ Anticancer activity of the thiosemicarbazone 89 having the chromone and adamantyl moieties against several cell lines has been evaluated. ${ }^{41}$<smiles>[R]c1ccc2oc(Nc3ccccc3)c(/C=N/NC(N)=S)c(=O)c2c1</smiles>

$88: \mathrm{R}=\mathrm{H}, \mathrm{Me}, \mathrm{F}, \mathrm{Cl}, \mathrm{Br}$<smiles>Nc1oc2ccc(Br)cc2c(=O)c1/C=N/NC(=S)NC12CC3CC(CC(C3)C1)C2</smiles>

89 
Heating an ethanolic solution of 2-( $N, N$-dimethyl- or -diethyl-amino)-8-isopropyl-5methylchromone-3-carbaldehyde together with $\mathrm{NH}_{2} \mathrm{NHR}^{1}\left(\mathrm{R}^{1}=\mathrm{H}, \mathrm{Me}, \mathrm{Ph}\right)$ affords 1benzopyrano[2,3-c]pyrazole 90. ${ }^{15}$ The amino-aldehyde 19 on warming with $\mathrm{NH}_{2} \mathrm{NHR}^{1}\left(\mathrm{R}^{1}=\mathrm{H}\right.$, $\mathrm{Ph}$ ) in ethanol for a short time gives the corresponding hydrazone which on prolonged heating in ethanol furnishes naphthopyranopyrazole 91. In the case of reaction of 19 [ $\mathrm{R}=i-\mathrm{C}_{3} \mathrm{H}_{7}$; $\mathrm{RR}=$ $\mathrm{CH}_{2}\left(\mathrm{CH}_{2}\right)_{2} \mathrm{CH}_{2}$ ] with hydrazine hydrate, the pyrazole $91\left(\mathrm{R}^{1}=\mathrm{H}\right)$ remains contaminated with the bishydrazone 92. ${ }^{16}$ When the aldehyde 3 is treated with $\mathrm{NH}_{2} \mathrm{NHPh}$ in refluxing $\mathrm{MeCN}$, the product 93 is sometimes accompanied by the isomeric compound $94 .^{27}$<smiles>[R]n1ncc2c(=O)c3c(C)ccc(C(C)C)c3oc21</smiles>

90<smiles>[R]n1ncc2c(=O)c3c(ccc4ccccc43)oc21</smiles>

91<smiles>[R20]c1oc2ccc3ccccc3c2c(=O)c1/C=N/N</smiles>

92<smiles>[R2]c1oc2ccc3ccccc3c2c(=O)c1C=N</smiles><smiles>O=c1c2ccccc2oc2c1cnn2-c1ccccc1</smiles>

A compound having an amino group bonded to a heterocyclic nitrogen behaves as a $N, N$ disubstituted hydrazine rather than a primary amine so as to undergo 1,2- (not 1,4) - addition to the $\alpha, \beta$-unsaturated aldehyde functionality of 2-amino-3-formylchromones 1-4. Thus, the 3aminoquinazoline $95\left(\mathrm{R}^{1}=\mathrm{H}, \mathrm{Br}\right)$ with the chromone 3 gives the hydrazone 96 that spontaneously cyclizes to the pentacyclic system 97 (Scheme 8). ${ }^{42,43}$<smiles></smiles>

\section{Scheme 8}

The hydrazone 98 derived from 2-amino-6,7-dimethylchromone-3-aldehyde and rhodamine B-hydrazide shows extremely high fluorescence enhancement upon forming a 1:1 complex with $\mathrm{Sn}^{4+}$; Density Functional Theory (DFT) computational study indicates it to be a nearly planar pentacoordinated $\mathrm{Sn}(\mathrm{IV})$ complex, the metal being coordinated with two carbonyl oxygens, the 
doubly bonded nitrogen and two chloride anions. This complex is selectively and fully reversible in the presence of sulfide anions. ${ }^{44}$

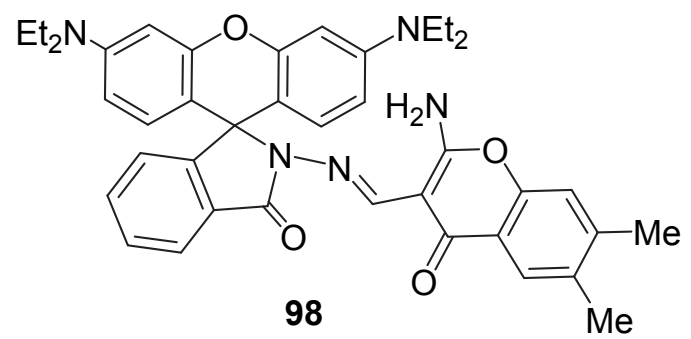

\subsection{Reaction with hydroxylamine}

When an ethanolic solution of the aldehyde 1 is heated with $\mathrm{NH}_{2} \mathrm{OH} . \mathrm{HCl}$ in the presence of an alkali, the initially formed amino-aldoxime 99 (三6) under alkaline conditions leads to 2-amino3-carbamoylchromone $\mathbf{1 0 0}$ that on further treatment with $\mathrm{NH}_{2} \mathrm{OH}$ gives the chromandione 101. ${ }^{45}$ The mechanisms of these transformations have been duly elaborated. ${ }^{46,47}$ The diamine $\mathbf{1 0 1}$ on acetylation forms an $E, Z$ mixture of the monoacetamide $\mathbf{1 0 2}$.<smiles>Nc1oc2ccccc2c(=O)c1/C=N/O</smiles>

99<smiles>NC(=O)c1c(N)oc2ccccc2c1=O</smiles>

100<smiles>NC(N)=C1C(=O)Oc2ccccc2C1=O</smiles>

101<smiles>NC(N)=C1C(=O)Oc2ccccc2C1=O</smiles>

102

\subsection{Reaction with amidines and thioamides}

The aldehyde 19 with the amidine 103 gives the benzopyranopyrimidine 104, acetamidine 103a and benzamidine 103b being used as their hydrochloride, guanidine 103c as its carbonate salt and $O$-methylisourea and $S$-methylisothiourea 103d,e as their sulfates, and pyridine being the reaction medium. ${ }^{48}$ The reaction of 19 with $\mathbf{1 0 3 d}$ in pyridine gives a product $(44 \%)$ structurally akin to the fused diazocine 9; the same reaction in EtOH-NEt ${ }_{3}$, however, gives 104d exclusively. ${ }^{48}$ Similarly the pyranopyrimidine $105\left(\mathrm{R}=\mathrm{Ph}, \mathrm{NH}_{2}, \mathrm{SMe}\right)$ is obtained from the appropriate 2-( $N, N$-dialkylamino)chromone-3-aldehyde and the amidine $\mathbf{1 0 3}{ }^{15}$<smiles>[R]C(=N)N</smiles>

103<smiles>[R]c1ncc2c(=O)c3c(ccc4ccccc43)oc2n1</smiles>

104<smiles>[R]c1ncc2c(=O)c3c(C)ccc(C(C)C)c3oc2n1</smiles>

For $103-105$ a : $R=M e$

b : $\mathrm{R}=\mathrm{Ph}$

c : $\mathrm{R}=\mathrm{NH}_{2}$

d : $\mathrm{R}=\mathrm{OMe}$

e : $\mathrm{R}=\mathrm{SMe}$

Thia-Michael addition of thiobenzamide (106) to the $\alpha, \beta$-unsaturated carbonyl functionality of 2-anilino-3-formylchromone (2) with concomitant pyran ring opening and recyclization gives the intermediate $\mathbf{1 0 7}$ that eliminates benzonitrile and water giving chromone-3-thioanilide (108) (Scheme 9). ${ }^{49,50}$ 


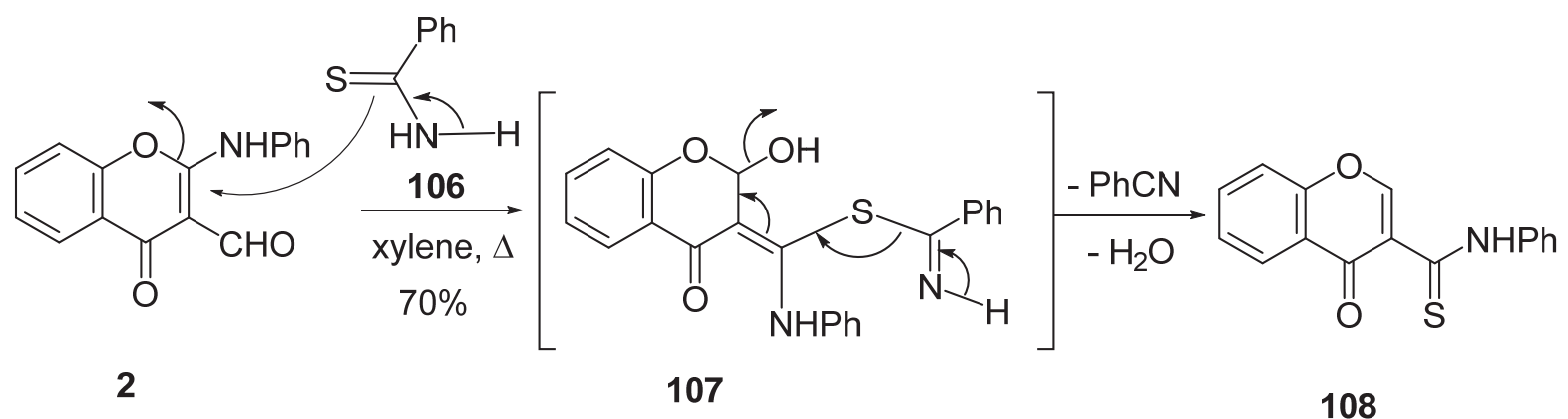

\section{Scheme 9}

\section{Reaction with Activated Alkynes and Alkenes}

2-Amino-3-formylchromone 1 in hot DMF undergoes through its amine function an aza-Michael addition to cyanoacetylene 109, the non-isolable Michael adduct 111 cyclizing to the 5-oxo-5 $\mathrm{H}$ [1]benzopyrano[2,3-b]pyridine $\mathbf{1 1 3}$ (henceforth this fused heterocyclic moiety will be considered as azaxanthone). The aldehyde $\mathbf{1}$ when heated with ethyl propiolate $\mathbf{1 1 0}$ in $\mathrm{Et}_{3} \mathrm{~N}-\mathrm{DMF}$ gives a mixture of $\mathbf{1 1 2}$ and 114, the former product on further heating in the above named solvent mixture cyclising to 114. The aldehyde 1 with $\alpha$-chloroacrylonitrile 115 gives through the intermediate 116 (isolable) the azaxanthone 113 (Scheme 10).,

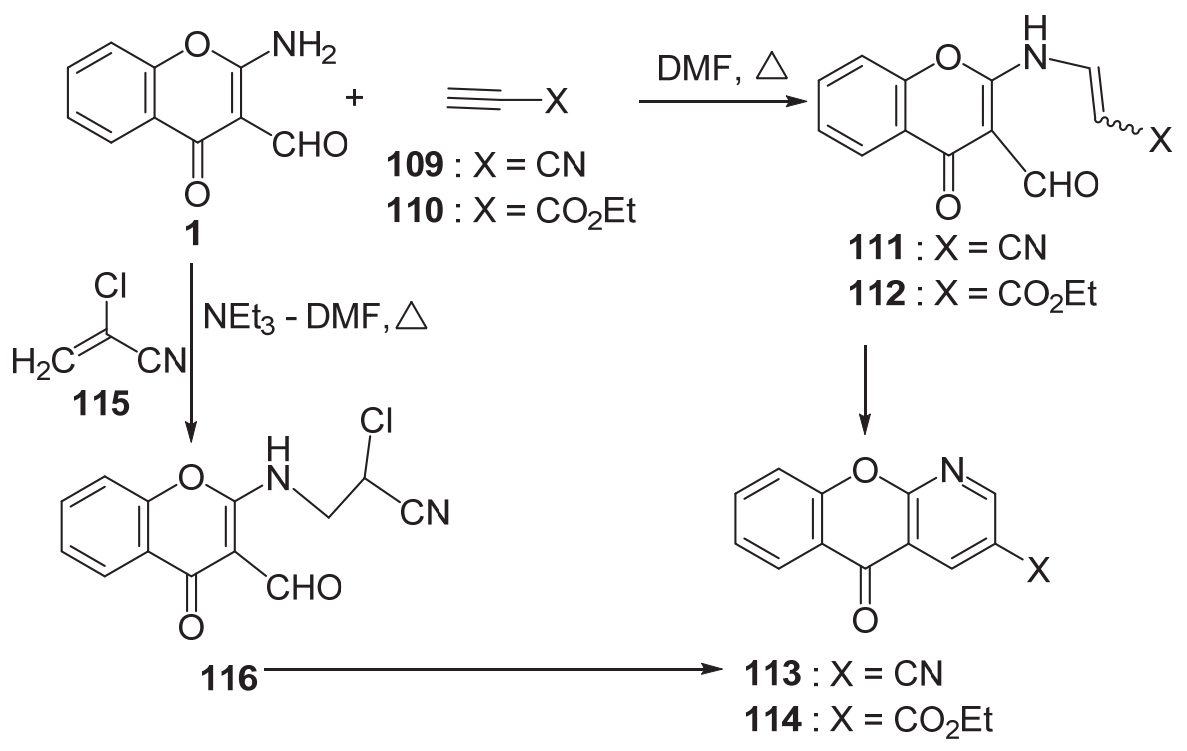

\section{Scheme 10}

The acetylenephosphonate 117 carrying a $\mathrm{CF}_{2} \mathrm{X}$ group has been employed in a base mediated heterocyclization reaction with the aldehyde 1 to give the 3-difluoromethyl-4azaxanthon-2-ylphosphonate 118 (Scheme 11). ${ }^{51}$ Condensation of 1 with $117\left(\mathrm{X}=\mathrm{H}, \mathrm{Cl}, \mathrm{F}, \mathrm{CF}_{3}\right)$ is best suited by method (i) and that with $117(\mathrm{X}=\mathrm{Br})$ by method (ii). 


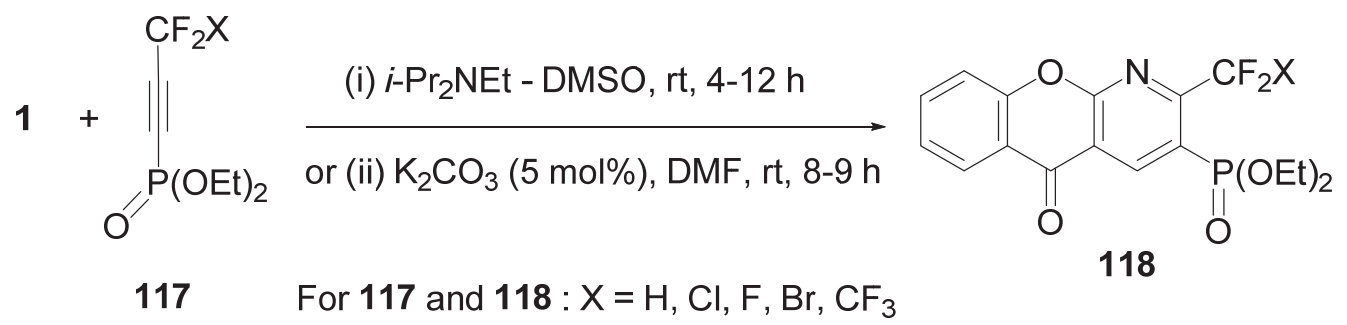

\section{Scheme 11}

Trapping by the aminoaldehyde 2 of the highly reactive 1:1 intermediate generated in the reaction between dialkyl acetylenedicarboxylate and triphenylphosphine in dichloromethane at ambient temperature results in the formation of the 3,4-dihydro-4-azaxanthone 119. ${ }^{52}$<smiles>[R]Nc1oc2ccccc2c(=O)c1C=O</smiles><smiles>[R]N1c2oc3ccccc3c(=O)c2C=C(F)C1F</smiles>

For 2 and 119 :

$\mathrm{R}^{1}=\mathrm{Ph}, \mathrm{C}_{6} \mathrm{H}_{4} \mathrm{OMe}-\mathrm{O}, \mathrm{CH}_{2} \mathrm{CO}_{2} \mathrm{Et}$;

$\mathrm{E}=\mathrm{CO}_{2} \mathrm{Me}, \mathrm{CO}_{2} \mathrm{Et}$

119

Heterocyclization of the aminoaldehyde $\mathbf{1}$ with benzyne is also known. 3-Fluoro-4methoxybenzyne 121 generated from 5-(3-fluoro-4-methoxyphenyl)thianthrenium perchlorate 120 and LDA in THF at reflux reacts with the chromone 1 to give the 1-benzopyrano[2,3-b]quinoline 122 in $70 \%$ yield (Scheme 12). ${ }^{53}$

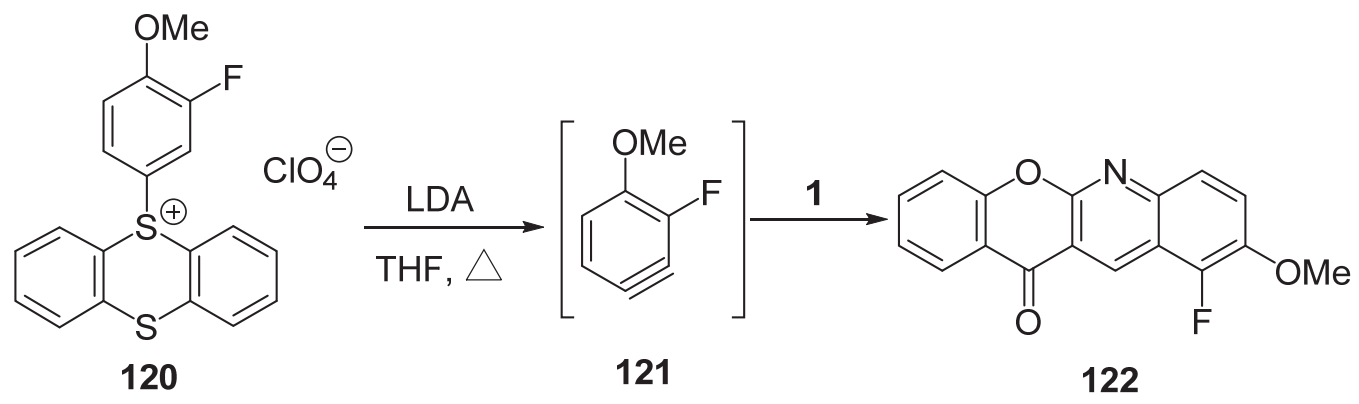

\section{Scheme 12}

\section{Friedländer Annulation}




\subsection{Annulation with active methylene compounds}

Friedländer annulation of the aldehyde 1 with compounds having either a $-\mathrm{CH}_{2} \mathrm{CO}-$ or a $-\mathrm{CH}_{2} \mathrm{CN}$ grouping has received a fillip since an earlier report on the synthesis of 4-azaxanthone derivatives 123-125 by a base catalyzed reaction of 1 with diethyl malonate, ethyl cyanoacetate and malononitrile, respectively. ${ }^{3}$ The aldehyde 1 with acetylacetone and ethyl acetoacetate in hot EtOH-piperidine gives 126 and 127 respectively. ${ }^{54}$ All these azaxanthones 123-127 have also been obtained in higher yields by reacting the nitrile 7 , the chemical equivalent of $\mathbf{1}$, with the appropriate active methylene compounds under base catalysis. ${ }^{54,55} \mathrm{~A}$ mixture of $\mathbf{1}$ and acetylglycine heated in $\mathrm{Ac}_{2} \mathrm{O}$ containing fused $\mathrm{NaOAc}$ under reflux produces the benzopyrano[2,3-b]pyridino[3,2- $d]$-oxazolone 128. ${ }^{6}$ 2-Amino-3-formyl-benzo[f]- and -benzo[ $\left.h\right]$ chromone behave similarly as their unsubstituted 2-amino-3-formylchromone 1 towards the above mentioned active methylene compounds. ${ }^{56}$ Friedländer annulations of 8-allyl-2-amino-3formylchromone with the cyano compound $129\left(\mathrm{X}=\mathrm{CN}, \mathrm{SPh}, \mathrm{CONH}_{2}, \mathrm{CO}_{2} \mathrm{Et}\right)$ in refluxing EtOH-DBU gives the azaxanthone 130. ${ }^{57}$ 2-Amino-3-formyl-6-methylchromone with $129(\mathrm{X}=$ $\mathrm{CONHN}=\mathrm{CHAr}$ ) under similar condition gives the product $131 .^{58}$<smiles>[X]c1cc2c(=O)c3ccccc3oc2nc1[R]</smiles>

\begin{tabular}{lll} 
& \multicolumn{1}{c}{$\mathbf{R}$} & \multicolumn{1}{c}{$\mathbf{X}$} \\
123 & $\mathrm{OH}$ & $\mathrm{CO}_{2} \mathrm{Et}$ \\
124 & $\mathrm{NH}_{2}$ & $\mathrm{CO}_{2} \mathrm{Et}$ \\
125 & $\mathrm{NH}_{2}$ & $\mathrm{CN}$ \\
126 & $\mathrm{Me}$ & $\mathrm{COMe}$ \\
127 & $\mathrm{Me}$ & $\mathrm{CO}_{2} \mathrm{Et}$
\end{tabular}<smiles>Cc1nc2cc3c(=O)c4ccccc4oc3nc2o1</smiles>

128<smiles>Cc1ccc2oc3nc(N)c(C(=O)N/N=C/C4CCCCC4)cc3c(=O)c2c1</smiles>

$131: \mathrm{Ar}=\mathrm{C}_{6} \mathrm{H}_{4} \mathrm{Cl}-p$

The aldehyde 1 is acylated by cyanoacetyl chloride in $\mathrm{CH}_{2} \mathrm{Cl}_{2}$ to 132 ; its cyclization product 133 is converted through 134 to 2-cyano-4-azaxanthone 113 obtainable also by heating a mixture of $\mathbf{1}$ and cyanoacetyl chloride with Vilsmeier reagent (Scheme 13). ${ }^{4,5}$

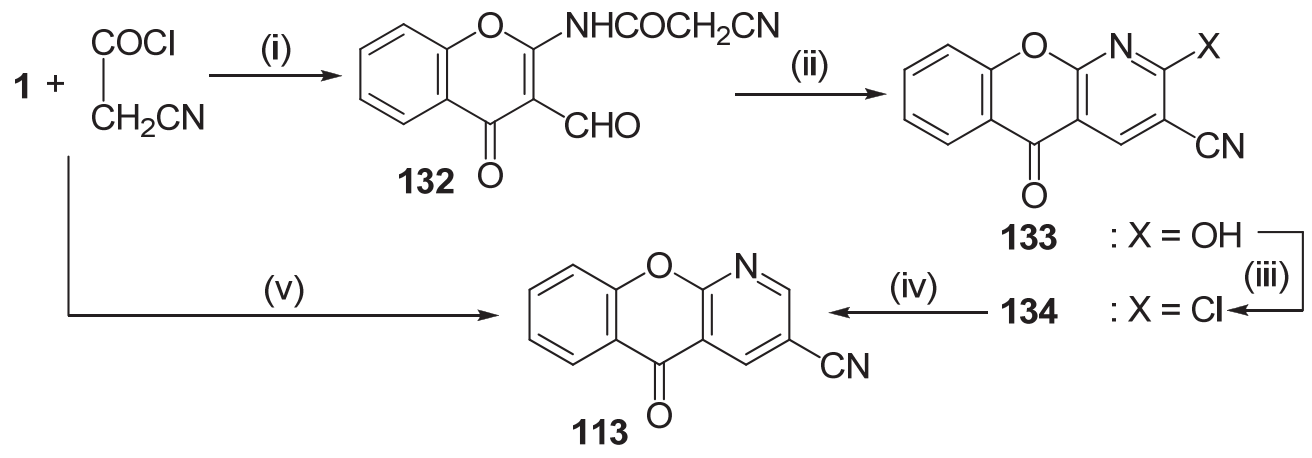


Scheme 13. Reagents and conditions : (i) $\mathrm{CH}_{2} \mathrm{Cl}_{2}$, warm; (ii) pyridine, $\Delta$; (iii) $\mathrm{POCl}_{3}-\mathrm{PCl}_{5}, 120$ ${ }^{\circ} \mathrm{C}$; (iv) Pd-C, $\mathrm{H}_{2}, \mathrm{DMF}-\mathrm{K}_{2} \mathrm{CO}_{3}$, rt; (v) $\mathrm{POCl}_{3}$-DMF.

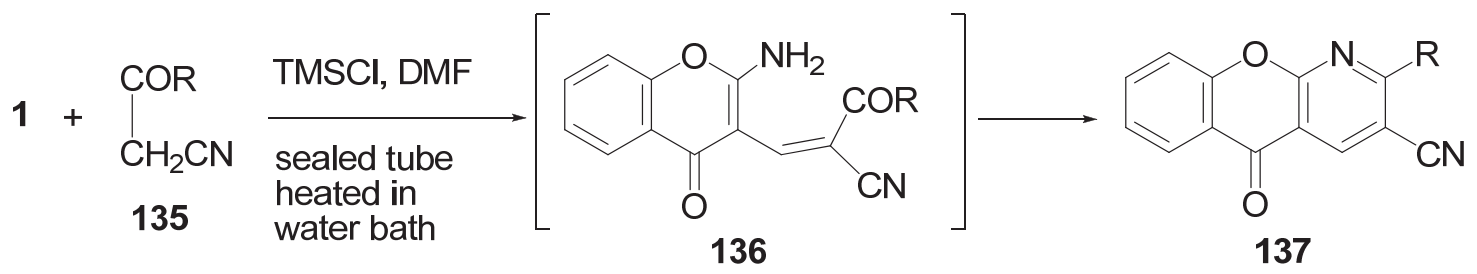

For 135-137 : R = p-chlorophenyl, thiophen-2-yl, benzofuran-2-yl

\section{Scheme 14}

Ryabukhin et al. ${ }^{59}$ condensed the aldehyde $\mathbf{1}$ with acylacetonitrile $\mathbf{1 3 5}$ and obtained through 136 the 2-cyanoazaxanthone 137 (Scheme 14) with complete exclusion of any 2-acyl-3aminoazaxanthone derivative.

Aryl- and hetaryl- acetonitriles have also been condensed with the aldehyde $\mathbf{1}$. The heterogeneous catalyst silica chloride $\left(\mathrm{SiO}_{2}-\mathrm{Cl}\right)$ prepared by treating oven dried silica gel in dry $\mathrm{CH}_{2} \mathrm{Cl}_{2}$ with $\mathrm{SOCl}_{2}$ at room temperature, induces Knoevenagel condensation of 1 with $p$-nitrophenylacetonitrile in ethanol at room temperature to give selectively the $Z$-isomer 138 in $\sim 90 \%$ yield. ${ }^{60}$ No attempt has been made to cyclize 138 to 3-amino-2-( $p$-nitrophenyl)-4-azaxanthone. Condensation of 1 with benzimidazol-2-ylacetonitrile 139 in boiling EtOH-NEt 3 affords the azaxanthone 140 in $65 \%$ yield. ${ }^{61}$ Under similar conditions the nitrile 139 with 3-cyanochromone 7 and its 6-methyl homologue produce the chromeno[3,2-e]pyrido[1,2-a]benzimidazole 142 and 141, respectively. ${ }^{61}$
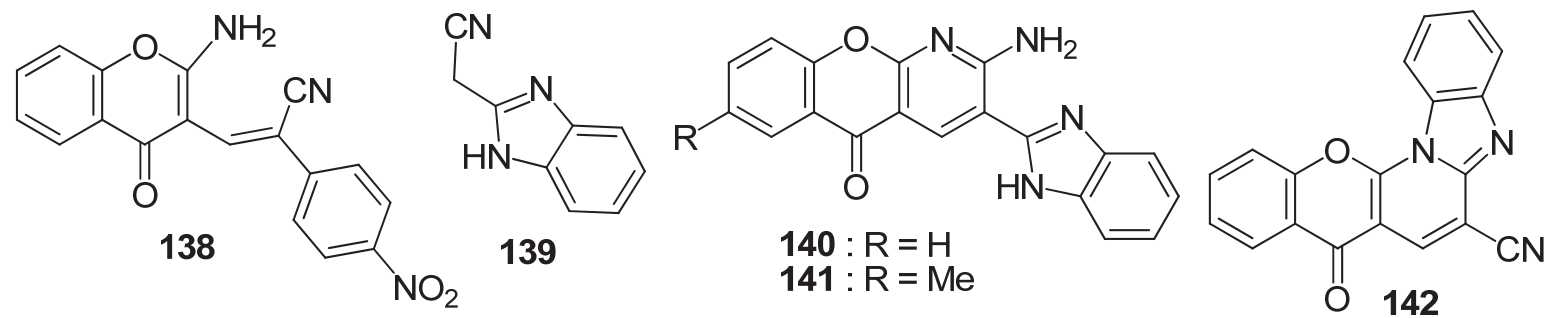

The results obtained by condensation of the chromone 1 with the acylnitromethane $143^{62}$ and $\beta$-ketoacid $\mathbf{1 4 6}^{63}$ are depicted in Schemes 15 and 16, respectively. The stereochemistry of the condensate 144 is not ascertained; it is, however, convertible into the azaxanthone $\mathbf{1 4 5}$. No intermediate is isolable in the formation of 145 by reacting 1 with 143 in refluxing DMF-DBU. The condensate $\mathbf{1 4 7}$ is most probably formed in $E$-isomeric form so as to undergo lactonization to 148 instead of giving any lactam. 


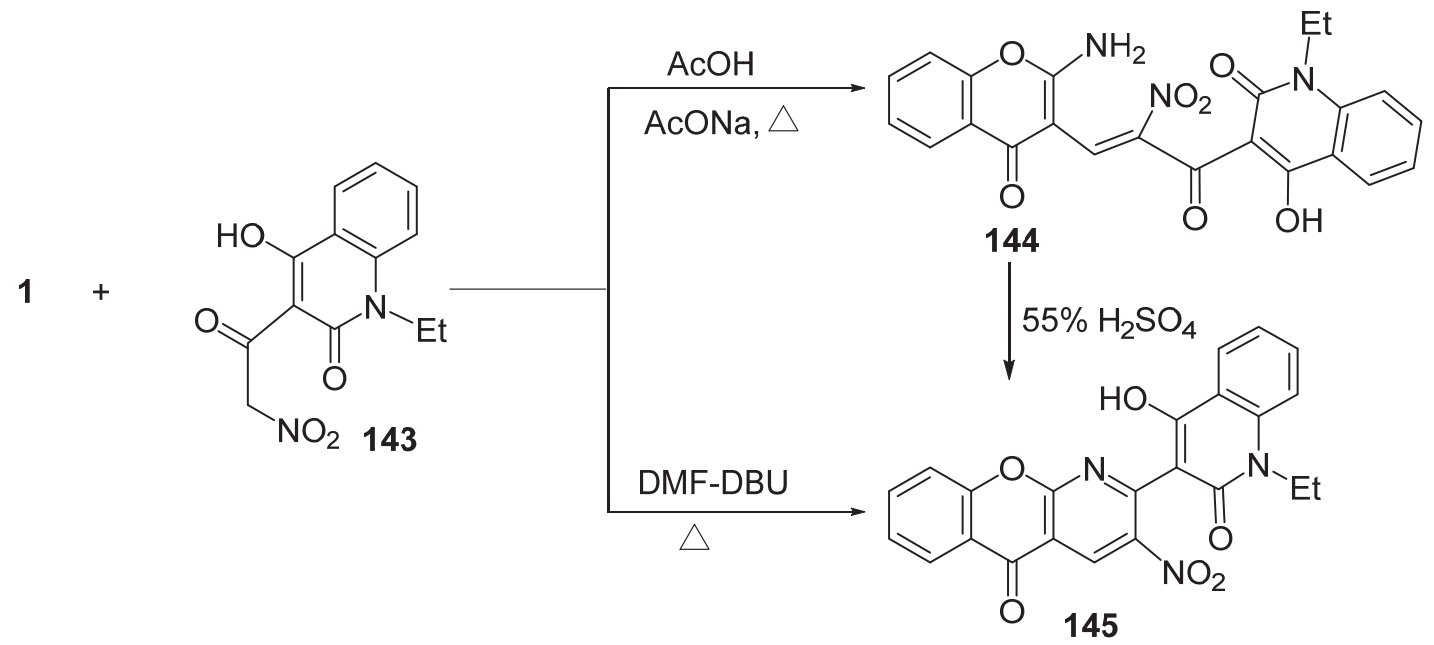

\section{Scheme 15}

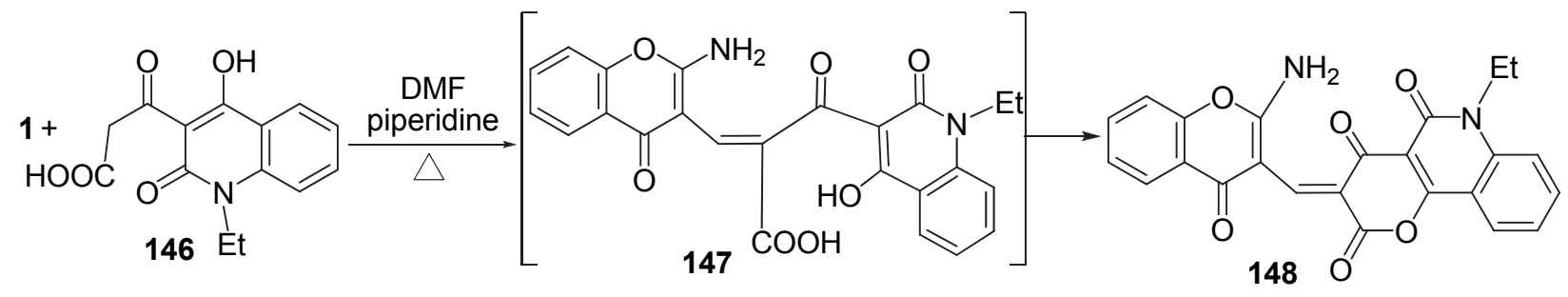

\section{Scheme 16}

Siddiqui $^{64}$ has developed a facile and green synthetic route to new benzopyrano[2,3b]pyridines 150a-e in excellent yields $(\sim 90 \%)$ via Friedländer condensation of the chromone 1 with cyclic active methylene compounds 149 containing a $-\mathrm{CO}-\mathrm{CH}_{2}-\mathrm{CO}$ - grouping in the presence of $\mathrm{Zn}$ (L-proline) $)_{2}$ as an efficient and stable Lewis acid catalyst in water (Scheme 17). Compounds $150 d^{57}$ and $150 f^{56}$ have also been synthesized by base catalyzed reaction of 1 with 149d and 149f, respectively.<smiles>O=C1CCCC(=O)CC1</smiles>

149<smiles>[X]CCc1nc2oc3ccccc3c(=O)c2cc1C(=O)CC</smiles>

150
For 149 and 150
a: $\mathrm{X}=-\mathrm{O}-\mathrm{CMe}_{2} \mathrm{O}$
b: $X=-N(M e)-C(=0)-N(M e)-$
c: $X=-\mathrm{NH}-\mathrm{C}(=\mathrm{S})-\mathrm{NH}-$
d: $\mathrm{X}=-\mathrm{NH}-\mathrm{C}(=\mathrm{O})-\mathrm{NH}-$
$\mathrm{e}: \mathrm{X}=\mathrm{s}^{5}$
f: $\mathrm{X}=-\mathrm{CH}_{2}-\mathrm{CMe}_{2}-\mathrm{CH}_{2}-$

\section{Scheme 17}


Compounds having their $\mathrm{CH}_{2} \mathrm{CO}$ grouping protected as dialkyl acetal can also condense with the aminochromone 1. Thus, malondialdehyde tetramethyl acetal 151 reacts with 1 in ether containing $\mathrm{BF}_{3} \cdot \mathrm{Et}_{2} \mathrm{O}, \mathrm{HCO}_{2} \mathrm{H}$ at $60^{\circ} \mathrm{C}$ to give the 2-formylazaxanthone 152 together with a small amount of its deformylated product $153 .{ }^{4,5} \mathrm{~N}, \mathrm{~N}$-dimethylacetamide dimethyl acetal 155 and 1methylpyrrolidine-2-one diethyl acetal 156 give with 1 the condensed products 154 and 157 , respectively. ${ }^{65}$

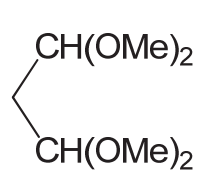

151<smiles>[X]c1cc2c(=O)c3ccccc3oc2nc1[R]</smiles>

$152: \mathrm{R}=\mathrm{H}, \mathrm{X}=\mathrm{CHO}$

$153: \mathrm{R}=\mathrm{X}=\mathrm{H}$

$154: \mathrm{R}=\mathrm{NMe}_{2}, \mathrm{X}=\mathrm{H}$

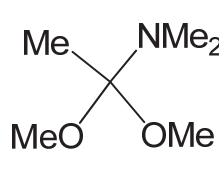

155

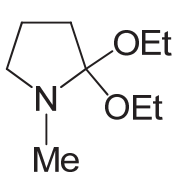

156<smiles>CN1CCc2cc3c(=O)c4ccccc4oc3nc21</smiles>

157

Maiti et $a l .{ }^{66}$ have extensively studied the condensation of 2-(monosubstituted amino)-3formylchromone $\mathbf{2}$ with several active methylene compounds. Condensation of $\mathbf{2}$ with Meldrum's acid, ethyl acetoacetate, ethyl benzoylacetate, diethyl malonate and hippuric acid gives pyranopyridones 158a-e, respectively. Acetonitrile $\mathrm{XCH}_{2} \mathrm{CN}\left(\mathrm{X}=\mathrm{CO}_{2} \mathrm{Et}, \mathrm{CN}\right)$, however, reacts differently with 1 under the same conditions to produce via the rarely isolable intermediate 159 the salicyloylpyridone 160. The aminochromone $161\left(\mathrm{R}^{2}=\mathrm{Me}, \mathrm{Et}\right)$ behaves similarly to 2 in its reaction with ethyl benzoylacetate, diethyl malonate and ethyl nitroacetate in refluxing pyridine-piperidine, but the fused pyridine $162(\mathrm{X}=\mathrm{CN}, \mathrm{PhCO})$ analogous to $\mathbf{1 5 9}$ is formed by reacting $161\left(\mathrm{R}^{2}=\mathrm{Et}\right)$ with $\mathrm{XCH}_{2} \mathrm{CN}(\mathrm{X}=\mathrm{CN}, \mathrm{PhCO}) .{ }^{67}$ The compound $158\left(\mathrm{R}^{2}=\mathrm{Ph}, \mathrm{PhCH}_{2}\right.$; $\mathrm{X}=\mathrm{H}$ ) is obtained by heating a mixture of the appropriate aminochromone $\mathbf{2}$ and $\mathrm{Ph}_{3} \mathrm{P}=\mathrm{CHCO}_{2} \mathrm{Et}$ in benzene under reflux. ${ }^{68}$<smiles>[R]Nc1oc2ccccc2c(=O)c1C=O</smiles>

2: $\mathrm{R}^{2}=\mathrm{Et}, \mathrm{Ph}, \mathrm{C}_{6} \mathrm{H}_{4} \mathrm{Me}-p$<smiles>[R]Nc1oc2ccc3ccccc3c2c(=O)c1C=O</smiles>

161<smiles>[X]c1cc2c(=O)c3ccccc3oc2n([R])c1=O</smiles>

158<smiles>[X]c1cc2c(=O)c3ccccc3oc2n([R])c1=N</smiles>

159<smiles>[X]c1cc(C(=O)c2ccccc2O)c(=O)n([R])c1N</smiles>

160<smiles>[X]c1cc2c(=O)c3c(ccc4ccccc43)oc2n(CC)c1=N</smiles>

162

Some reactive methylene compounds take a reaction course other than Friedländer annulation with the amino-aldehyde $\mathbf{1}$. As for example, chloroacetamide $\mathbf{1 6 3}$ reacts with the 
aldehyde 1 to give the pyrrolopyran 165 via 164 (Scheme 18). ${ }^{69}$ The compound 165 shows high activity against Alternaria alternata, Aspergillus niger and A. flavipes.

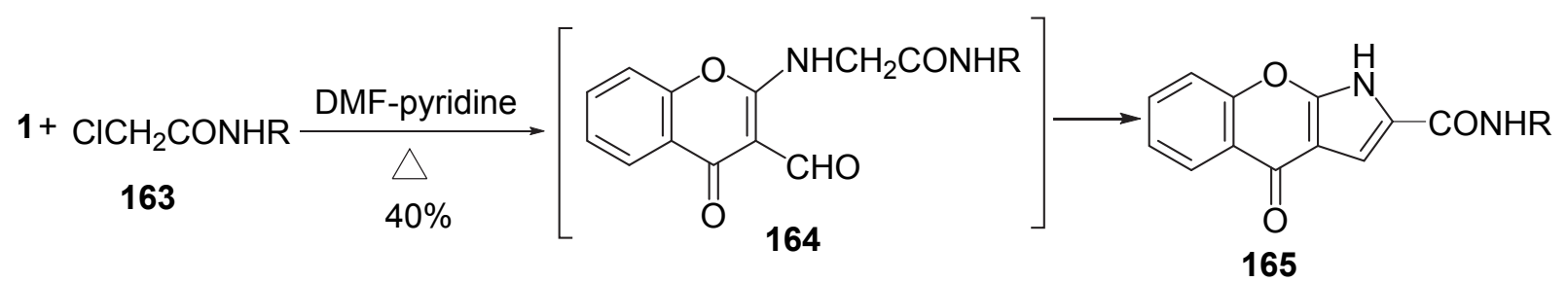<smiles>O=c1c(/C=N/c2ccc(Nc3cccs3)cc2)coc2ccc(Cl)cc12</smiles>

\section{Scheme 18}

When an intimate mixture of the aldehyde 1 , phenylhydrazine, ethyl acetoacetate, $\mathrm{SiO}_{2}$, catalytic amount of $\mathrm{ZnBr}_{2}$ and a small amount of water is subjected to microwave heating at $60^{\circ} \mathrm{C}$ for $10-15 \mathrm{~min}$, the compound $\mathbf{1 6 7}(95 \%)$ results. ${ }^{70}$ In this one-pot three-component reaction the phenylhydrazine at first forms with ethyl acetoacetate the pyrazolidinone $\mathbf{1 6 6}$ that condenses with 1 giving 167.
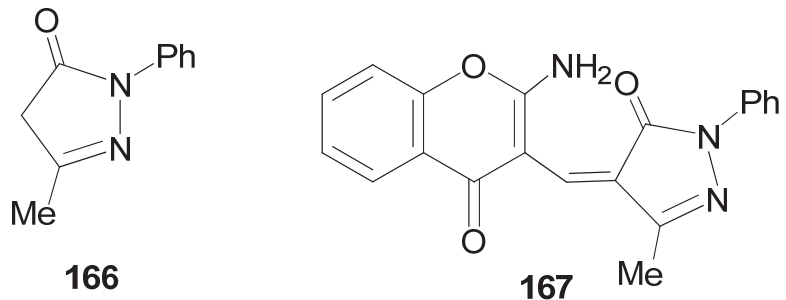

\subsection{Annulation with aryl and hetaryl methyl ketones}

The azaxanthones 168-170 are obtained by treating the chromone 1 with acetophenone, 1indanone and 1-tetralone, respectively under mild reaction conditions $\left(4: 1 \mathrm{MeCN}-\mathrm{H}_{2} \mathrm{O}, \mathrm{rt}, 8 \mathrm{~h}\right)$ by employing $\mathrm{AuCl}_{3}-\mathrm{AgSbF}_{6}$ catalyzed aldol reaction as the key step. ${ }^{71}$ The chromone $\mathbf{1}$ as well as its 8-allyl analogue on condensation with the ketone $\mathbf{1 7 1}$ in refluxing EtOH-DBU gives the azaxanthone $172{ }^{72,73}$ 
<smiles>[R]c1ccc(-c2ccc3c(=O)c4ccccc4oc3n2)cc1</smiles>

$168: R=H, 3-M e, 4-M e$<smiles>[R]C(C)=O</smiles>

171<smiles></smiles>

$169: \mathrm{n}=1$

$170: n=2$

For 171 and $172: \mathrm{R}=\mathrm{H}, \mathrm{CH}_{2}-\mathrm{CH}=\mathrm{CH}_{2}$ $\mathrm{R}^{1}=\mathrm{C}_{6} \mathrm{H}_{4} \mathrm{Cl}-p$, 2-thiophenyl, 3-pyridyl,<smiles>Cc1c(O)[nH]c(=O)sc1=O</smiles><smiles>Cc1cc(O)c(C)c(=O)o1</smiles>

\subsection{Annulation with alkyl methyl ketones}

Highly regioselective Friedländer annulation of hexan-2-one with the chromone 1 employing 1,3,3-trimethyl-6-azabicyclo[3.2.1] octane (TABO) as a catalyst gives the products $\mathbf{1 7 3}$ and 174 in $4: 1$ proportions (Scheme 19), the major product 173 being obtained in nearly $70 \%$ yield. $^{74}$<smiles>CCCCc1ccc2c(=O)c3cc(-c4ccc([18OH])cc4)ccc3oc2n1</smiles>

\section{Scheme 19}

Regioselective facile Friedländer synthesis of four different sugar based azaxanthone derivatives of the general structure 176 (Scheme 20) has been achieved and their activity against different microbes assessed. ${ }^{75}$

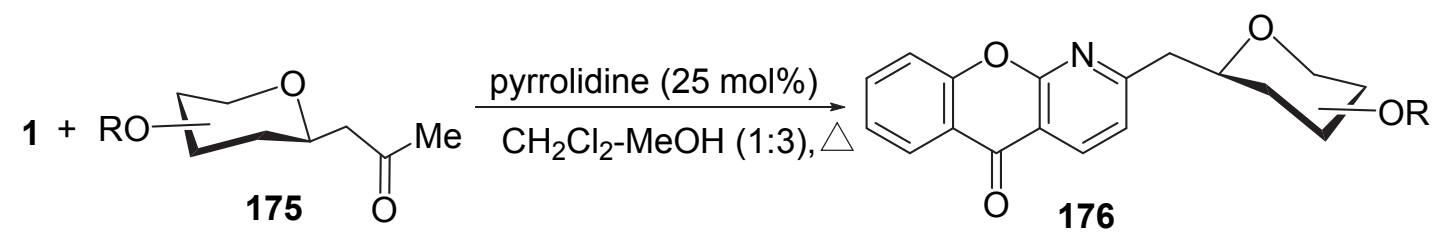

For 175 and 176 : OR represents a number of $\mathrm{OH}$ or OAc groups in the pyanose sugars

\section{Scheme 20}

\subsection{Annulation with enols and enamines}

Triacetic acid lactone (TAL) 177 has been annulated with the chromone $\mathbf{1}$ in pyridine-piperidine at room temperature to yield the pyranopyridine $178 .^{76,77}$ Condensation of 4-hydroxycoumarin 
<smiles>Cc1cc(O)cc(=O)o1</smiles>

177<smiles>CC(=O)/C=C(\O)c1cc2c(=O)c3ccccc3oc2[nH]c1=O</smiles>

178<smiles>O=c1c2ccccc2oc2nc3oc4ccccc4c(=O)c3cc12</smiles>

179<smiles>[X]C(=O)c1cc2c(=O)c3ccccc3oc2nc1-c1ccccc1[X]</smiles>

180: $X=0$

$181: X=$ NMe<smiles>CCn1c(=O)c2c(=O)c3cc4c(=O)c5ccccc5oc4nc3oc2c2ccccc21</smiles>

$\mathrm{HO}$<smiles></smiles><smiles>CCn1c(=O)c2c(O)cc(=O)oc2c2ccccc21</smiles><smiles>CC(C)(C)[Na]</smiles><smiles>[R]n1c(=O)c(C(=O)c2ccccc2O)cc2c(=O)c3ccccc3oc21</smiles><smiles>[R]n1c(=O)c2cc3c(=O)c4ccccc4oc3nc2n([R])c1=O</smiles>

with 1 is reported to give one or more of the products $179, \mathbf{1 8 0}$ and $182 .{ }^{77-81}$ Heating the chromone $\mathbf{1}$ in isopropanol- $\mathrm{HCl}^{78}$ or a mixture of $\mathbf{1}$ and 4-hydroxycoumarin in $\mathrm{MeOH}$-pyridine ${ }^{77}$ gives the pentacycles 179 and 180 associated with the tricoumarol 182, ${ }^{79}$ but only 180 in refluxing ethanol ${ }^{80}$ or DMF-DBU. ${ }^{81}$ The heterocyclic enols 183-185 with the chromone 1 in refluxing DMF-DBU afford the fused azaxanthones 181, 186 and 187, respectively. ${ }^{81} 2-(N-$ alkylamino)-3-formylchromone $2\left(\mathrm{R}^{2}=\mathrm{Et}, \mathrm{Ph}\right)$ with 4-hydroxycoumarin in refluxing EtOHpyridine gives the salicyloylxanthone 188. ${ }^{66}$ The enamines $\mathrm{MeC}\left(\mathrm{NH}_{2}\right)=\mathrm{CH}-\mathrm{X}(\mathrm{X}=\mathrm{COMe}$ or $\mathrm{CO}_{2} \mathrm{Et}$ ) condense with the chromone 1 giving the azaxanthones 126 and 127 , respectively. ${ }^{56}{ }_{4-}$ Aminouracil $^{81}$ and 4-amino-1,3-dimethyluracil ${ }^{56}$ with the chromone 1 give the tetracycles 189 and 190, respectively.

\section{Amine-Formalin Mediated Conversion of 2-( $N$-Alkyl/aryl-amino)-3- formylchromones}

The aminochromone $2\left(\mathrm{R}^{2}=\mathrm{Me}, \mathrm{Et}, \mathrm{Ph}, \mathrm{C}_{6} \mathrm{H}_{4} \mathrm{Me}-p\right)$ when heated with a secondary amine such as sarcosine, piperidine or diethylamine in the presence of excess of formalin in DMF under reflux affords 3,3'-methylenebischromone 191, the yield of the $N$-aryl- and $N$-alkyl product 191 being $\sim 90 \%$ and $43 \%$, respectively. ${ }^{82}$ When heated in methanol with glycine in the presence of an excess of formalin, the chromone $\mathbf{2}$ undergoes organocatalytic rearrangement; 2arylaminochromone $2\left(\mathrm{R}^{2}=\mathrm{Ph}, \mathrm{C}_{6} \mathrm{H}_{4} \mathrm{Me}-p\right)$ gives the anilide 192 but $N$-alkylaminochromone 2 $\left(\mathrm{R}^{2}=\mathrm{Me}, \mathrm{Et}\right)$ the chroman-2,4-dione $16^{83}$ 


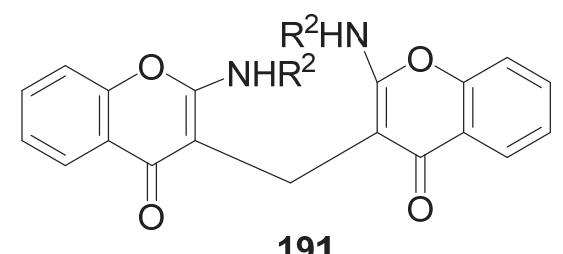

191

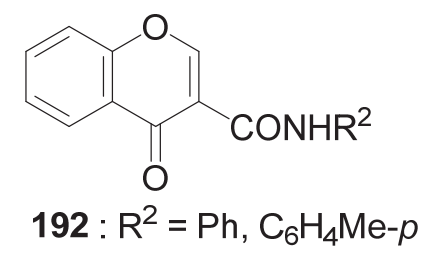

\section{Conversion of 2-Arylamino-3-formylchromones into [1]Benzopyrano- $[2,3-b] q u i n o l o n e s$}

2-Phenylamino-3-formylchromone 2 cyclizes to the benzopyranoquinoline $\mathbf{1 9 3}$ on refluxing with anhydrous $\mathrm{AlCl}_{3}$ in $\mathrm{CCl}_{4}$ followed by treatment with sulfuric acid, ${ }^{11}$ heating in $70 \%$ or conc. sulfuric acid ${ }^{13,25}$ or by heating with a secondary amine as sarcosine, piperidine or $\mathrm{Et}_{2} \mathrm{NH}$ in DMF under reflux. ${ }^{82}$ The chromone $\mathbf{2 b}\left(\mathrm{R}^{2}=\beta\right.$-naphthyl) on heating in conc. $\mathrm{H}_{2} \mathrm{SO}_{4}$ transforms into the naphthopyridine $194 .^{25}$ The chromone 3 on treatment with $m$-phenylenediamine in refluxing $\mathrm{H}_{2} \mathrm{O}-\mathrm{MeCN}$ (80:20) gives the fused quinoline 195 through the intermediacy of the aminochromone $\mathbf{2 b}\left(\mathrm{R}^{2}=m\right.$-aminophenyl). ${ }^{27}$<smiles>[R]c1cc2nc3oc4ccccc4c(=O)c3cc2c([R])c1C</smiles>

$$
\begin{aligned}
& 193: R^{1}-R^{3}=H \\
& 194: R^{1} R^{2}=C H=C H-C H=C H ; R^{3}=H \\
& 195: R^{1}=R^{2}=H ; R^{3}=N_{2}
\end{aligned}
$$

2-( $N$-alkyl- $N$-aryl)chromone $\mathbf{3}$ obtained by alkylation of the chromone $\mathbf{2}$ with the appropriate alkyl halide in the presence of $\mathrm{K}_{2} \mathrm{CO}_{3}$ and $\mathrm{NaI}$ in refluxing $\mathrm{MeCN}$ is transformed on heating in aq. AcOH into 3-salicyloylquinolin-2-one 198 instead of any fused quinoline derivative (Scheme 21). ${ }^{84}$ The $N$-disubstituted aminochromone 3 cyclizes to the fused quinoline 196; attack of a water molecule at its 5a-position (oxa Michael addition) causes pyran ring opening and the resultant intermediate 197 by tautomerization and water elimination gives 198. 


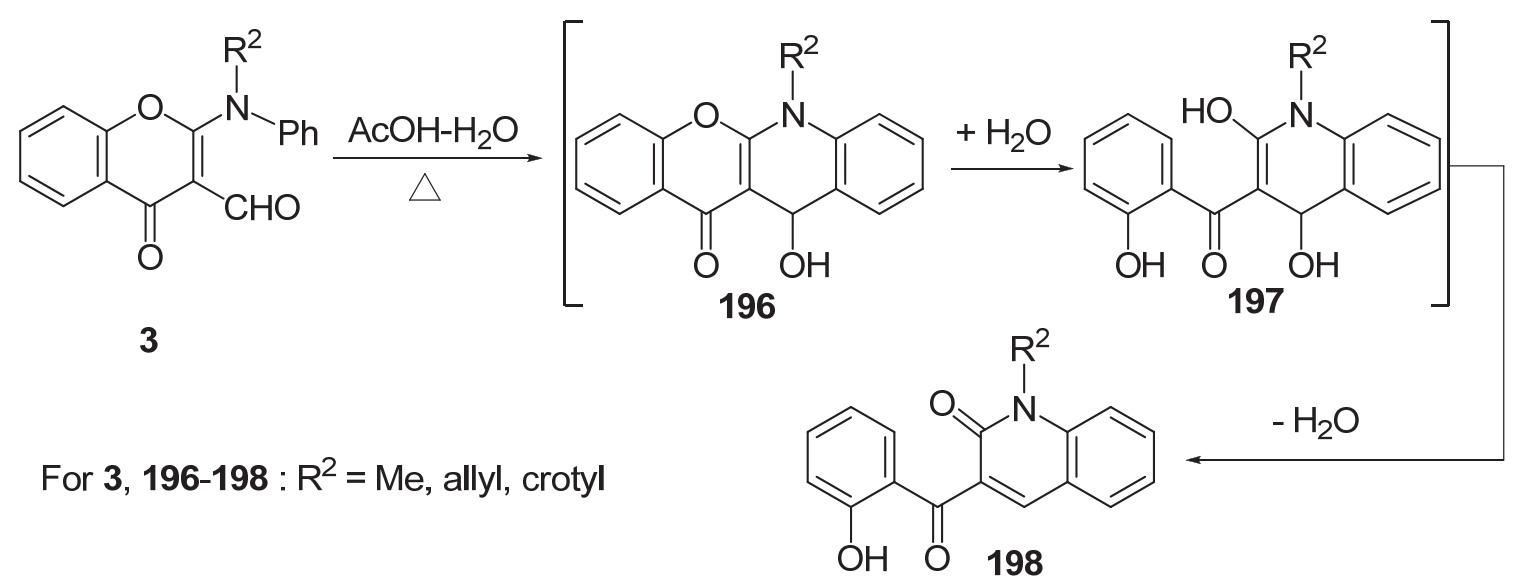

\section{Scheme 21}

\section{Reactions of 2-(N-Alkenyl- $N$-arylamino)-3-formylchromones}

The chromone 3b ( $\equiv \mathbf{1 9 9})$, obtained by alkylation of $\mathbf{2 b}(\mathrm{Ar}=\mathrm{Ph}, p$-tolyl) with an appropriate allyl bromide, on treatment with the amine 200 in $\mathrm{MeCN}$ at ambient temperature gives a mixture of the amine exchange product $\mathbf{2 0 1}$ and the corresponding aldimine in its tautomeric form 202, a small amount of $\mathbf{3 b}$ remaining unreacted. The same reaction under Lewis acid $\left(\mathrm{FeCl}_{3}, \mathrm{BF}_{3}\right.$. $\mathrm{Et}_{2} \mathrm{O}$ or $\mathrm{InCl}_{3}$ ) catalysis affords either of the chromenonaphthyridines 204 and 205 (Scheme 22) in poor to moderate yield, the Brønsted acid triphenylphosphonium perchlorate (TPP) (40 mol\%) giving the best results. ${ }^{85}$ The aldimine 203 initially formed by acid catalyzed condensation of 199 with 200 undergoes intramolecular imino-Diels-Alder reaction (IIDA) (Povarov reaction); endo-approach of the dienophile part in $\mathbf{2 0 3}$ is favoured when $\mathrm{R}^{2}=$ Me to form $\mathbf{2 0 4}$ whereas favourable exo-approach of that in $\mathbf{2 0 3}\left(\mathrm{R}^{2}=\mathrm{Ph}\right)$ leads to the trans fused product $\mathbf{2 0 5}$.<smiles></smiles>

3b ( $\equiv$ 199)

$\mathrm{Ar}=\mathrm{Ph}, \mathrm{C}_{6} \mathrm{H}_{4} \mathrm{Me}-p$

$\mathrm{R}^{1}=\mathrm{H} ; \mathrm{R}^{2}=\mathrm{H}, \mathrm{Me}, \mathrm{Ph}$

$\mathrm{R}^{1}=\mathrm{R}^{2}=\mathrm{Me}$<smiles>[Z]c1ccc(N)cc1</smiles>

200<smiles>[Z20]CNc1oc2ccccc2c(=O)c1C=O</smiles>

201<smiles>[Z20]CCN=C1Oc2ccccc2C(=O)C1=CNC[R6]</smiles>

For 200-202: Z = Me, OMe 


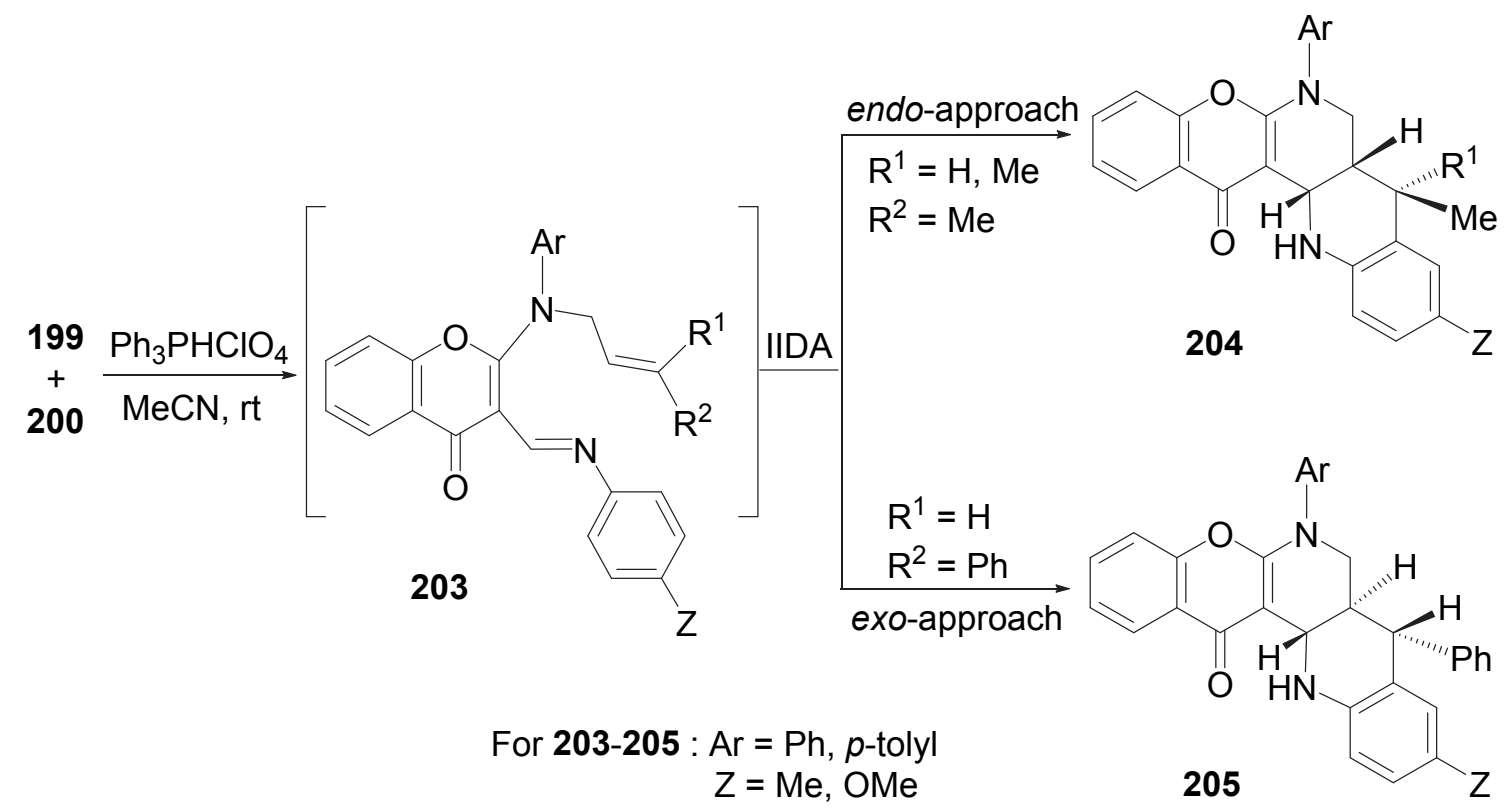

\section{Scheme 22}

When an equimolar mixture of the chromone $199\left(\mathrm{R}^{1}=\mathrm{H}\right)$ and sarcosine is subjected to conventional heating in toluene or microwave irradiation, the resultant azomethine ylid intermediate 206 undergoes regio- and stereo-selective intramolecular [3+2]cycloaddition giving the pyrrolo[2,3-a] azaxanthone $\mathbf{2 0 7}$ in good yields (Scheme 23). ${ }^{86}$

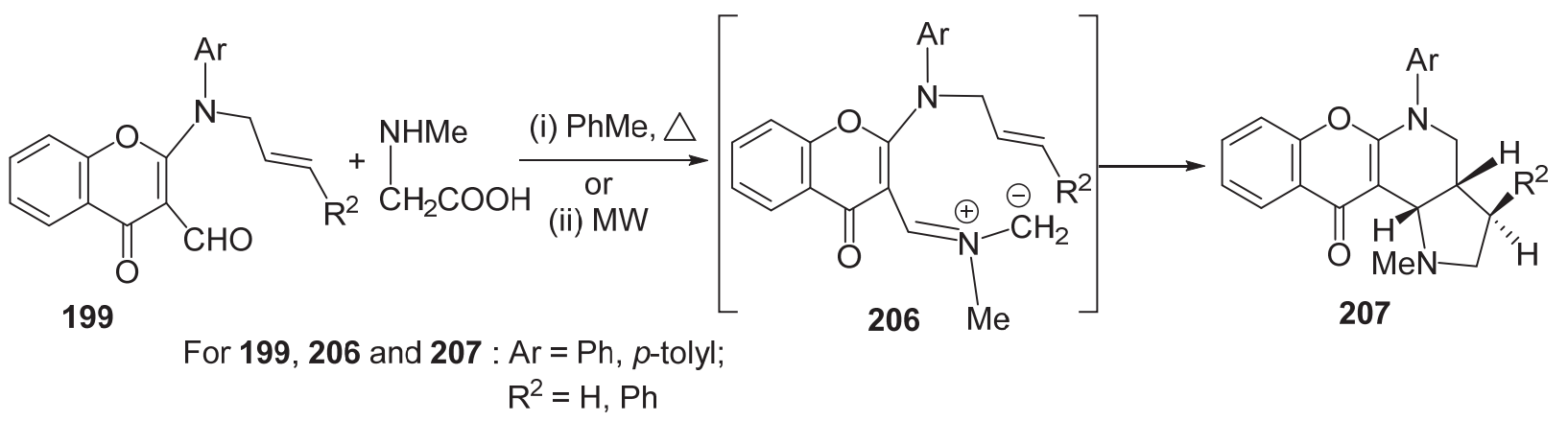

\section{Scheme 23}

Regio- and stereo-selective intramolecular [3+2]cycloaddition of the nitrone $\mathbf{2 0 8}$ generated in situ from the chromone $199\left(\mathrm{Ar}=\mathrm{Ph} ; \mathrm{R}^{1}=\mathrm{H}\right)$ and $N$-methylhydroxyamine leads to the chromenopyridine fused isoxazole 209 (80-90\%), sometimes associated with the amide 210 as a minor product (Scheme 24). ${ }^{87,88}$ 


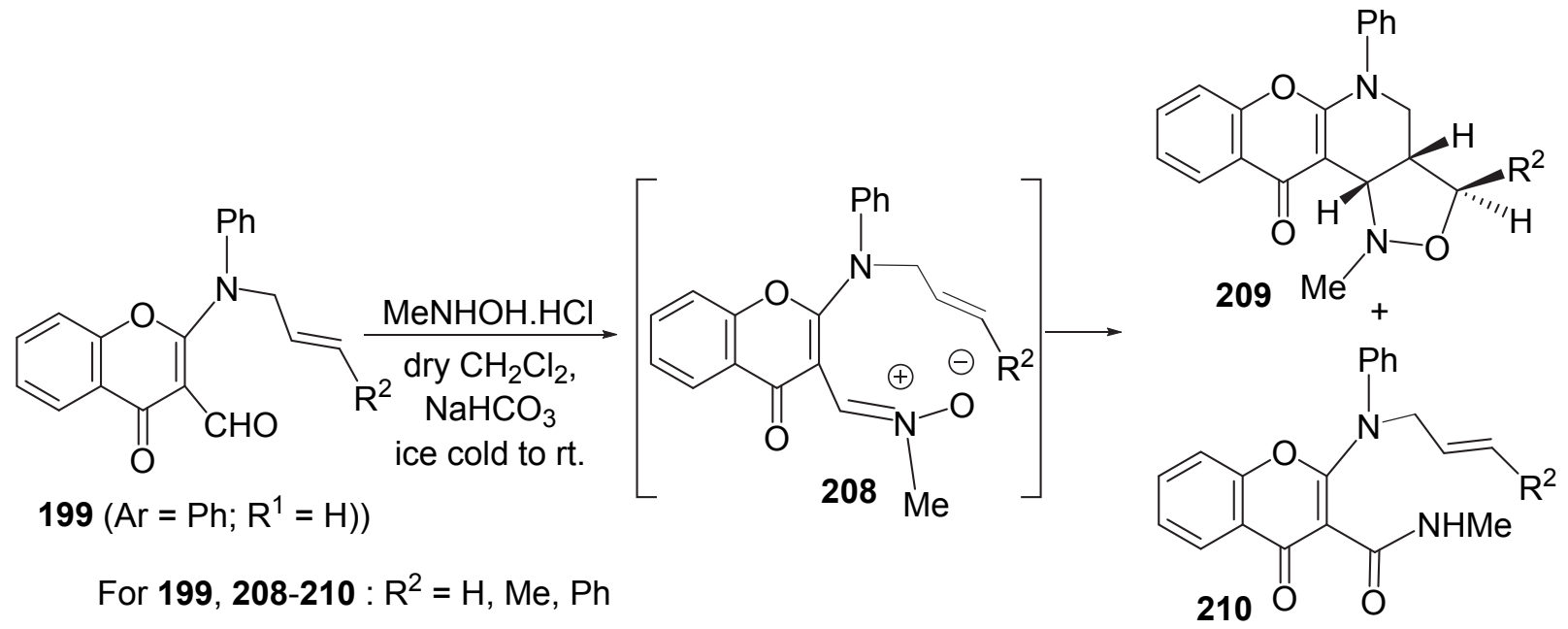

\section{Scheme 24}

Base catalyzed condensation of 199 with nitroalkane $\mathrm{R}^{3} \mathrm{CH}_{2} \mathrm{NO}_{2}$ gives the nitroalkene 211. The compounds $211\left(\mathrm{R}^{1}=\mathrm{R}^{3}=\mathrm{H} ; \mathrm{R}^{2}=\mathrm{H}, \mathrm{Me}, \mathrm{Ph}\right)$ are stable and fail to undergo [4+2]nitroalkene - olefin cycloaddition whereas other Henry condensation products $\mathbf{2 1 1}\left(\mathrm{R}^{1}=\mathrm{H}\right.$, $\mathrm{Me} ; \mathrm{R}^{2}=\mathrm{Me}, \mathrm{Ph} ; \mathrm{R}^{3}=\mathrm{PhCO}, \mathrm{CO}_{2} \mathrm{Et}$ ) undergo intramolecular hetero-Diels-Alder reaction to afford the polycyclic nitronates 212. The nitronates $212\left(\mathrm{R}^{3}=\mathrm{H}\right)$ undergo further transformations in the presence of a base. For example, $212\left(R^{1}=R^{2}=M e ; R^{3}=H\right)$ is not stable, but via 213 and 214 is transformed into the fused furanone $\mathbf{2 1 5}$ (Scheme 25). ${ }^{89}$

Wittig reaction of its aldehyde function with ethyl (triphenylphosphoranylidene)acetate converts the aminochromone 199 ( $R$ in place of $\mathrm{Ar} ; \mathrm{R}^{1}=\mathrm{H}$ ) into the benzopyran-3-ylacrylic ester 216. This ester 216 when dissolved in xylene and the solution heated in sealed tube at 220$230{ }^{\circ} \mathrm{C}$ undergoes a [1,5]allyl shift, the intermediate 217 cyclizing to the chromenopyridine $\mathbf{2 1 8}$, migration of phenyl or benzyl group in $\mathbf{2 1 6}$ being completely ruled out (Scheme 26). ${ }^{68}$ The fused pyridone $218\left(\mathrm{R}=\mathrm{Ph}, \mathrm{R}^{2}=\mathrm{H}\right)$ and its 8-chloro- and 8-fluoro- analogues have been evaluated in vitro for the cytotoxicity activity against various human cancer cell lines. ${ }^{90}$ 


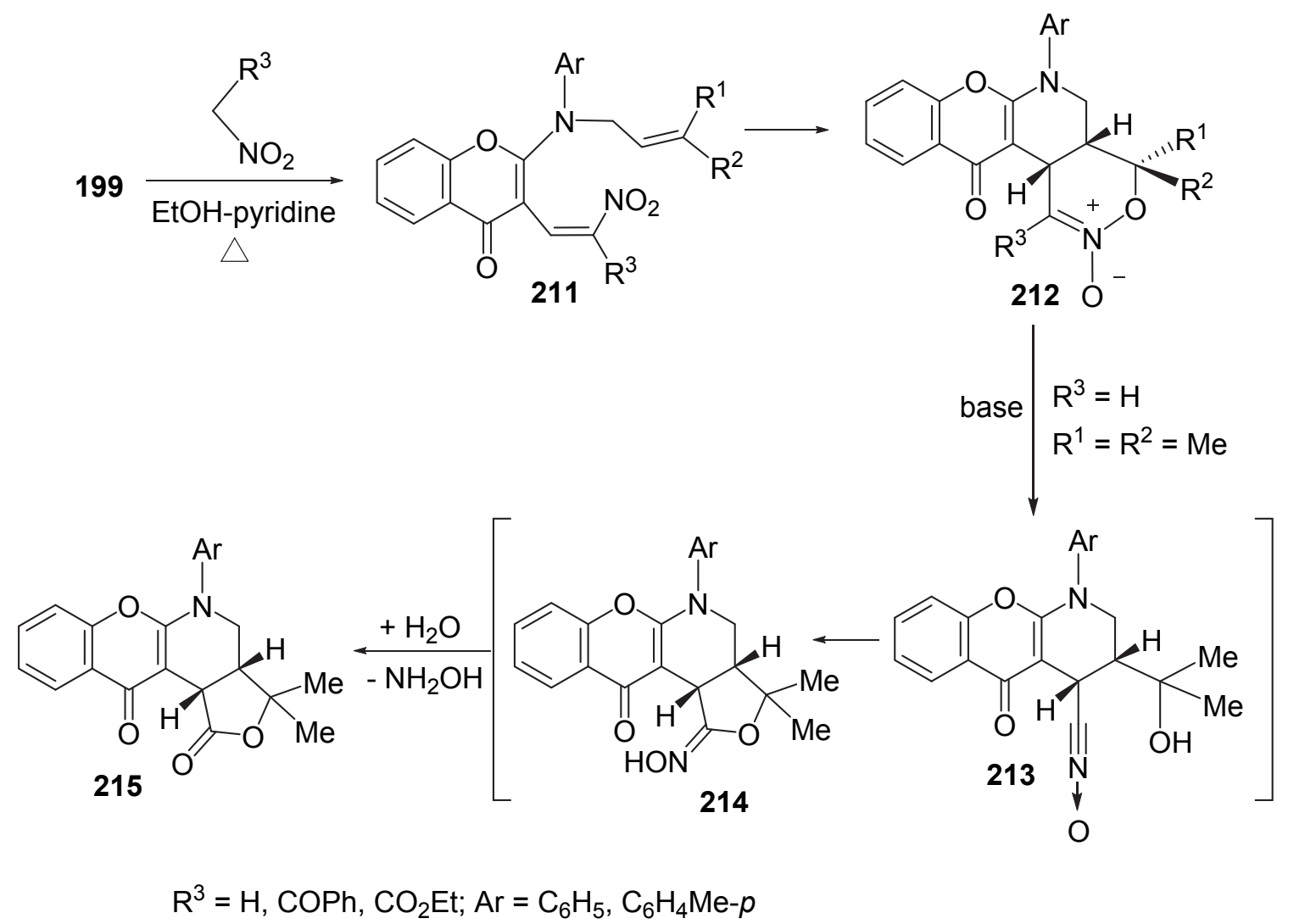

\section{Scheme 25}

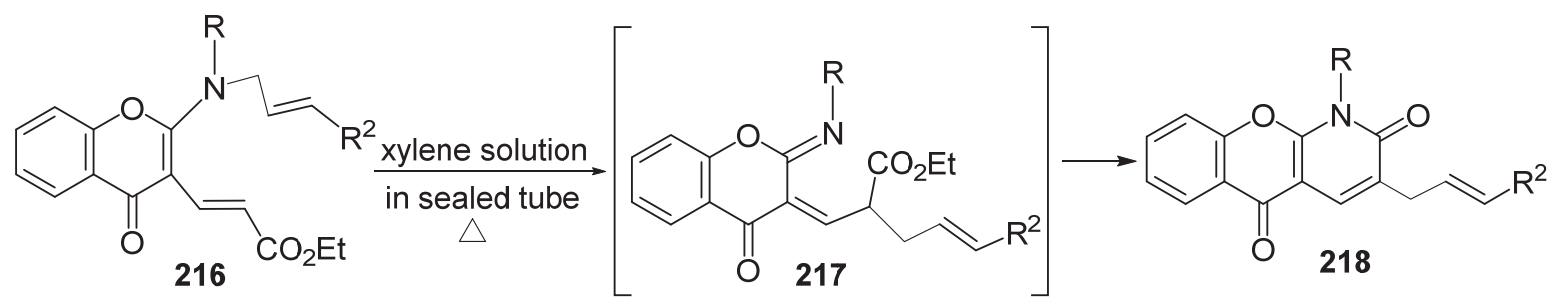

For 216-218: $\mathrm{R}=\mathrm{Ph}, \mathrm{PhCH}_{2} ; \mathrm{R}^{2}=\mathrm{H}, \mathrm{Me}, \mathrm{Ph}$

\section{Scheme 26}

The aminochromone 199 with active methylene compounds such as dimedone, Meldrum's acid and 4-hydroxycoumarin in refluxing ethanol-pyridine initially gives the non-isolable Knoevenagel condensates, the nature of the substituents on $N$-atom of its amino group determining the subsequent reaction courses. A competitive reaction between intramolecular Michael-type reaction (phenyl group functioning as nucleophile) and intramolecular hetero Diels-Alder reaction has been controlled by regulating the substituents on the $\mathrm{N}$ atom as well as on the dienophile unit. ${ }^{91}$ Thus, the condensate 219 obtained from 199 and dimedone having 
terminal alkene cyclizes to the benzopyranoquinoline 220 (Scheme 27 - path $a$ ) but that with a non-terminal alkene undergoes intramolecular hetero-Diels-Alder reaction with endo-approach of the olefinic moiety yielding the cis-fused product $\mathbf{2 2 3}$ (path $b$ ). It is worth mentioning here that $223\left(\mathrm{R}^{1}=\mathrm{R}^{2}=\mathrm{H}\right.$; Me or Et in place of Ar) also arises by base catalyzed reaction of 2- $(N-$ methyl or ethyl- $N$-allylamino)-3-formylchromone $199\left(\mathrm{R}^{1}=\mathrm{R}^{2}=\mathrm{H}\right.$; Me or Et in place of Ar) with dimedone. The chromone 199 having non-terminal alkene on its amino nitrogen gives the tetracycle 224 with Meldrum's acid and a mixture of hexacycles 225 and 226 with 4hydroxycoumarin. $^{91}$

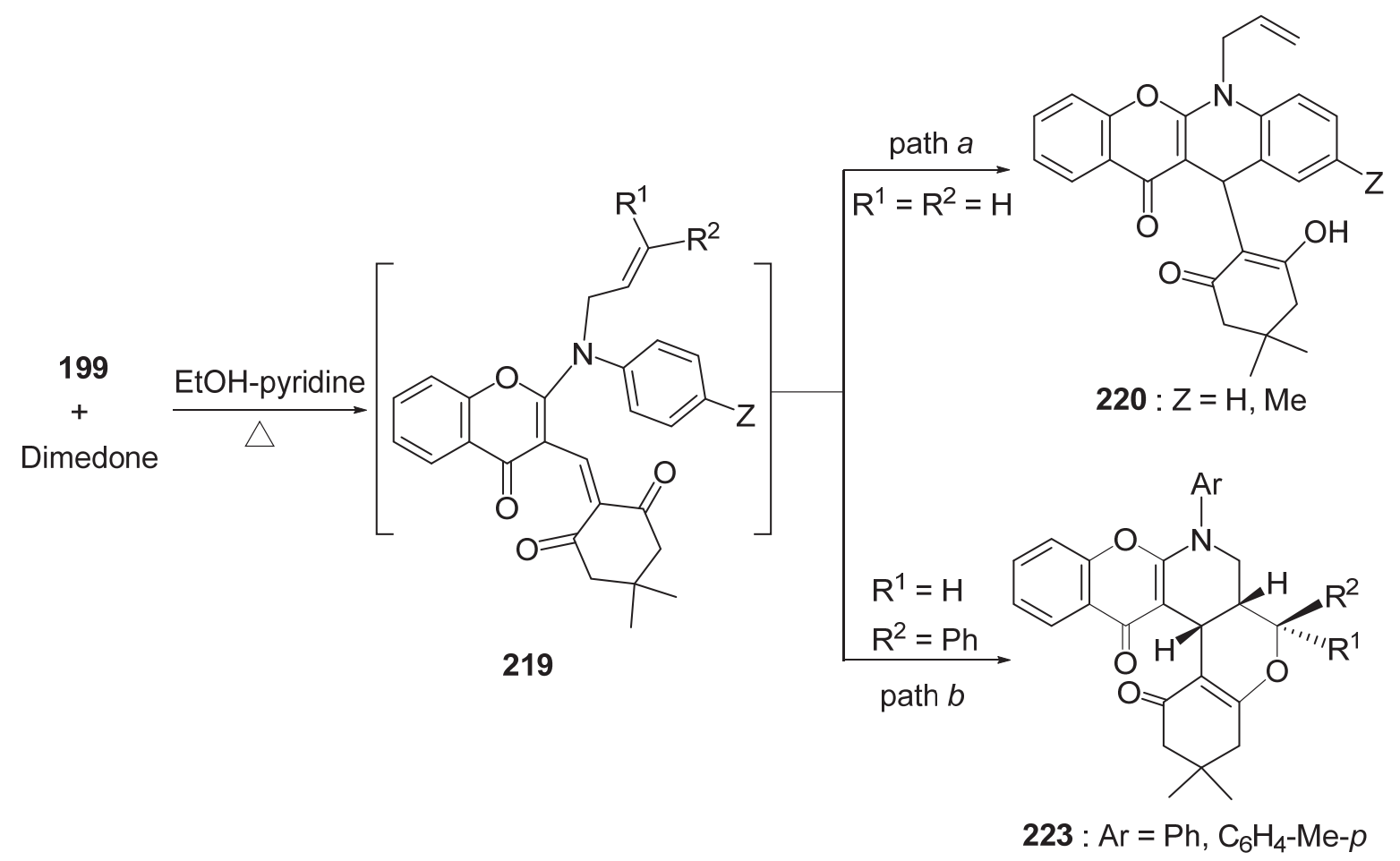

\section{Scheme 27}<smiles>[R4]C1CC2(CC(=O)OC2[R])CN([Al])c2oc3ccccc3c(=O)c21</smiles>

For 225-226: $\mathrm{Ar}=\mathrm{Ph}, \mathrm{C}_{6} \mathrm{H}_{4} \mathrm{Me}-\mathrm{p}$ $\mathrm{R}^{1}=\mathrm{H}, \mathrm{Me} ; \mathrm{R}^{2}=\mathrm{Me}, \mathrm{Ph}$

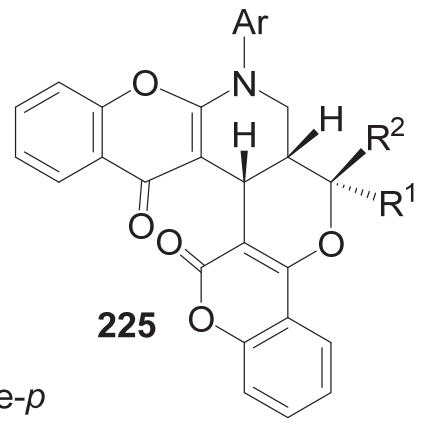

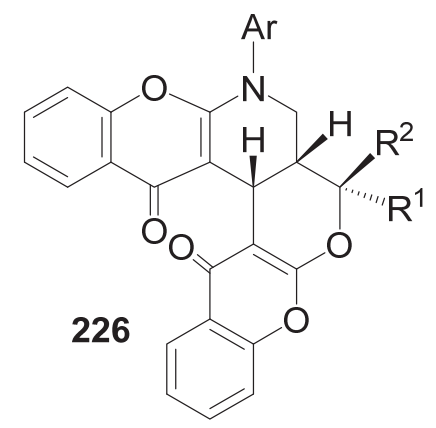




\section{Reactions of 2-( $N$-Alkynyl- $N$-arylamino)-3-formylchromones}

Treatment of the aminochromone $\mathbf{2 b}$ with $\mathrm{Br}-\mathrm{CH}_{2}-\mathrm{C} \equiv \mathrm{C}-\mathrm{R}$ in refluxing acetonitrile containing $\mathrm{K}_{2} \mathrm{CO}_{3}$ and $\mathrm{NaI}$ under an argon atmosphere gives 2-( $N$-alkynyl- $N$-arylamino)-3-formylchromone 3c (三 227). The chromone $227(\mathrm{R}=\mathrm{H})$ undergoes $\mathrm{I}_{2}-\mathrm{CuI}\left(\mathrm{I}_{2}-1\right.$ equiv., $\mathrm{CuI}-0.2$ equiv. stirring in $\mathrm{MeCN}$ at ambient temperature under argon atmosphere) mediated intramolecular alkyne carbonyl metathesis (ACM) reaction yielding the chromeno[2,3-b]azepin-3,6-dione 228; the chromone $227(\mathrm{R}=\mathrm{Me})$ fails to undergo ACM reaction. ${ }^{92}$

Microwave irradiation of a well ground equimolar mixture of $227(\mathrm{R}=\mathrm{Me}, \mathrm{Ph})$ and dimedone undergoes domino Knoevenagel - hetero-Diels-Alder (DKHDA) reaction furnishing pyrano-azaxanthone 229 whereas conventional heating of $227(\mathrm{R}=\mathrm{Me})$ admixed with dimedone in ethanol-pyridine causes its ACM to the acylazaxanthone $\mathbf{2 3 0} .{ }^{93}$
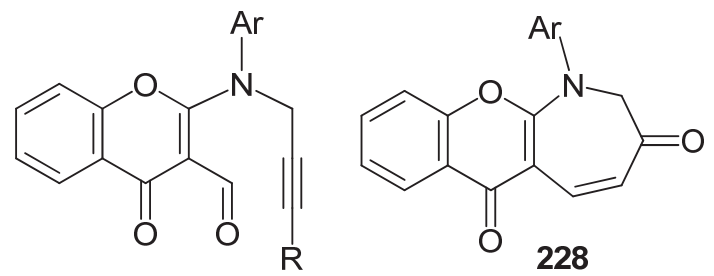

$227: \mathrm{R}=\mathrm{H}, \mathrm{Me}, \mathrm{Ph}$

For 227-230 : $\mathrm{Ar}=\mathrm{C}_{6} \mathrm{H}_{4}-\mathrm{X}-p ; \mathrm{X}=\mathrm{H}, \mathrm{Me}, \mathrm{Cl}, \mathrm{OMe}$

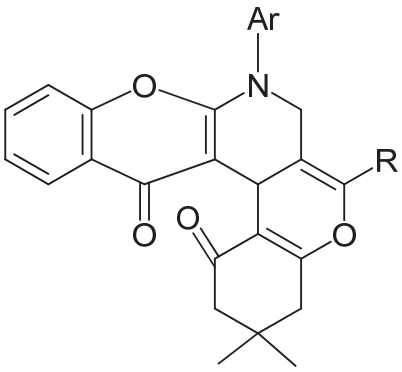

$229: \mathrm{R}=\mathrm{Me}, \mathrm{Ph}$<smiles>CC(=O)C1=Cc2c(oc3ccccc3c2=O)N(C)C1</smiles>

\section{Conclusion}

Syntheses of all the members 1-4 belonging to the 2-amino-3-formyl-1-benzopyran-4-one family, and their reactions with various nucleophiles and electrophiles, published to March 2016 have been comprehended.

\section{References}

1. Ghosh, C. K.; Chakraborty, A. Arkivoc 2015, (vi), 288-361 for a recent review on 3formylchromone.

http://dx.doi.org/10.3998/ark.5550190.p009.020

2. Ghosh, C. K.; Chakraborty, A. Arkivoc 2016, (i), 111-149 for a recent review on 3-acyl-2methylchromone.

http://dx.doi.org/10.3998/ark.5550190.p009.449

3. Petersen, U.; Heitzer, H. Liebigs Ann. Chem. 1976, 1659-1662.

http://dx.doi.org/10.1002/jlac.197619760913 
4. Ishiguro, T.; Ukawa, K.; Sugihara, H.; Nohara, A. Heterocycles 1981, 16, 733-740. http://dx.doi.org/10.3987/R-1981-05-0733

5. Nohara, A.; Ishiguro, T.; Ukawa, K.; Sugihara, H.; Maki, Y.; Sanno, Y. J. Med. Chem. 1985, $28,559-568$.

http://dx.doi.org/10.1021/jm50001a005

6. Ghosh, C. K.; Tewari, N. J. Org. Chem. 1980, 45, 1964-1968.

http://dx.doi.org/10.1021/jo01298a042

7. Ghosh, C. K.; Bhattacharyya, S.; Ghosal, N.; Achari, B. J. Chem. Res. (S) 1998, 178-179; (M) 1998, 859-862. http://dx.doi.org/10.1039/A706609K

8. Ghosh, C. K.; Tewari, N.; Bandyopadhyay, C. Indian J. Chem. 1983, 22B, 1200-1204.

9. Sosnovskikh, V. Y.; Moshkin, V. S.; Eltsov, O. S. Russ. Chem. Bull. 2010, 59, 2151-2154. http://dx.doi.org/10.1007/s11172-010-0372-0

10. Ghosh, C. K.; Karak, S. K. J. Heterocycl. Chem. 2005, 42, 1035-1042. http://dx.doi.org/10.1002/jhet.5570420601

11. Ishar, M. P. S.; Kumar, K.; Singh, R. Tetrahedron Lett. 1998, 39, 6547-6550. http://dx.doi.org/10.1016/S0040-4039(98)01362-8

12. Bandyopadhyay, C.; Sur, K. R.; Patra, R.; Sen, A. Tetrahedron 2000, 56, 3583-3587. http://dx.doi.org/10.1016/S0040-4020(00)00269-6

13. Ghosh, T.; Bandyopadhyay, C. Tetrahedron Lett. 2004, 45, 6169-6172. http://dx.doi.org/10.1016/j.tetlet.2004.06.033

14. Bandyopadhyay, C.; Sur, K. R.; Patra, R.; Banerjee, S. J. Chem. Res. (S) 2003, 459-460. http://dx.doi.org/10.3184/030823403103174812

15. Balbi, A.; Roma, G.; Mazzei, M.; Sottofattori, E.; Cadel, S.; Schiantarelli, P. Farmaco 1989, 44, 565-577.

16. Roma, G.; Ermili, A.; Mazzei, M. J. Heterocycl. Chem. 1975, 12, 31-35. http://dx.doi.org/10.1002/jhet.5570120106

17. Biswas, P.; Ghosh, J.; Sarkar, T.; Bandyopadhyay, C. J. Chem. Res. 2015, 39, 734-737. http://dx.doi.org/10.3184/174751915X14477880702453

18. Arjmand, F.; Sayeed, F.; Muddassir, M. J. Photochem. Photobiol. 2011, 103, 166-179. http://dx.doi.org/10.1016/j.jphotobiol.2011.03.001

19. Arjmand, F.; Jamsheera, A.; Afzal, M.; Tabassum, S. Chirality 2012, 24, 977-986. http://dx.doi.org/10.1002/chir.22081

20. Booysen, I. N.; Adebisi, A.; Akerman, M. P. Inorg. Chim. Acta 2015, 433, 13-20. http://dx.doi.org/10.1016/j.ica.2015.04.031

21. Numa, M. M. D.; Lee, L. V.; Hsu, C.-C.; Bower, K. E.; Wong, C.-H. ChemBioChem. 2005, 6, 1002-1006. http://dx.doi.org/10.1002/cbic.200500009

22. Sottofattori, E.; Grandi, T.; Balbi, A. Tetrahedron Lett. 1995, 36, 1331-1332. http://dx.doi.org/10.1016/0040-4039(94)02469-R 
23. Sottofattori, E.; Anzaldi, M.; Mazzei, M.; Miele, M.; Balbi, A.; Pyshnyi, D. S.; Zakharova, O. D.; Abranova, T. V. Bioorg. Med. Chem. 2005, 13, 1515-1522. http://dx.doi.org/10.1016/j.bmc.2004.12.030

24. Sottofattori, E.; Anzaldi, M.; Balbi, A.; Artali, R.; Bombieri, G. Helv. Chim. Acta 2002, 85, 1698-1705. http://dx.doi.org/10.1002/1522-2675(200206)85:6<1698::AID-HLCA1698>3.0.CO;2-B

25. Singh, G.; Singh, R.; Girdhar, N. K.; Ishar, M. P. S. Tetrahedron 2002, 58, 2471-2480. http://dx.doi.org/10.1016/S0040-4020(02)00128-X

26. Singh, G.; Singh, G.; Ishar, M. P. S. Synlett 2003, 256-258. http://dx.doi.org/10.1055/s-2003-36780

27. Singh, G.; Singh, L.; Ishar, M. P. S. Tetrahedron 2002, 58, 7883-7890. http://dx.doi.org/10.1016/S0040-4020(02)00908-0

28. Ishar, M. P. S.; Singh, G.; Singh, S.; Sreenivasan, K. K.; Singh, G. Bioorg. Med. Chem. Lett. 2006, 16, 1366-1370. http://dx.doi.org/10.1016/j.bmcl.2005.11.044

29. Ghosh, C. K.; Ghosh, C.; Patra, A. Indian J. Chem. 1998, 37B, 387-390.

30. Ibrahim, M. A.; El-Mahdy, K. Phosphorus, Sulfur, Silicon, Relat. Elem. 2009, 184, 29452958. http://dx.doi.org/10.1080/10426500802625594

31. Sosnovskikh, V. Y.; Moshkin, V. S.; Kodess, M. I. Tetrahedron Lett. 2009, 50, 6515-6518. http://dx.doi.org/10.1016/j.tetlet.2009.09.028

32. Roma, G.; Ermili, A.; Balbi, A.; Massa, E.; DiBraccio, M. J. Heterocycl. Chem. 1981, 18, 1619-1623. http://dx.doi.org/10.1002/jhet.5570180827

33. Praveen, M.; Azaz, S.; Malla, A. M.; Ahmad, F.; da Silva, P. S. P.; Ramos, S. M. New J. Chem. 2015, 39, 469-481. http://dx.doi.org/10.1039/C4NJ01666A

34. Sosnovskikh, V. Y.; Moshkin, V. S.; Kodess, M. I. J. Heterocycl. Chem. 2010, 47, 629633.

http://dx.doi.org/10.1002/jhet.370

35. Lazarenkow, A.; Nawrot-Modranka, J.; Brezinska, E.; Krajewska, U.; Rozalski, M. Med. Chem. Res. 2012, 21, 1861-1868.

http://dx.doi.org/10.1007/s00044-011-9703-4

36. Bevan, P. S.; Ellis, G. P.; Hudson, H. V.; Romney-Alexander, T. M.; Williams, J. M. J. Chem. Soc., Perkin Trans. 1 1986, 1643-1649. http://dx.doi.org/10.1039/P19860001643

37. Marwani, H. M. Asian J. Chem. 2011, 23, 4528-4532. http://www.asianjournalofchemistry.co.in/User/ViewFreeArticle.aspx?ArticleID=23 107 $\underline{4}$ 
38. Huang, S. S. C.; Ren, S.; Tokes, Z. A.; Csipke, C.; Guan, Y.; Chou, T.-C.; Bonaz-Krause, P.; Zyrianov, Y.; Mckenna, C. E.; Lien, E. J. Med. Chem. Res. 2002, 11, 168-194. http://eurekamag.com/research/011/325/011325812.php

39. Shebl, M.; Ibrahim, M. A.; Khalil, S. M. E.; Stephan, S. L.; Habib, H. Spectrochim. Acta Part A: Mol. Biomol. Spectroscopy 2013, 115, 399-408. http://dx.doi.org/10.1016/j.saa.2013.06.075

40. Singh, G.; Sharma, S. J. Chem. Pharm. Res. 2015, 7, 599-605. http://jocpr.com/vol7-iss5-2015/JCPR-2015-7-5-599-605.pdf

41. Gokhale, N.; Sanjay, J. Int. J. Pharm. Sci. Res. 2015, 6, 1792-1804. http://dx.doi.org/10.13040/IJPSR.0975-8232.6(4).1792-04

42. Gajbhiye, A.; Reddy, V. M.; Achaiah, G. Indian J. Heterocycl. Chem. 2007, 16, 235-238.

43. Sharma, A.; Patil, S.; Achaiah, G.; Gajbhiye, A. Oriental J. Chem. 2007, 23, 951-955.

44. Mahapatra, A. K.; Manna, S. K.; Mandal, D.; DasMukhopadhyay, C. Inorg. Chem. 2013, 52, 10825-10834. http://dx.doi.org/10.1021/ic4007026

45. Sosnovskikh, V. Y.; Moshkin, V. S.; Kodess, M. I. Tetrahedron Lett. 2008, 49, 6856-6859. http://dx.doi.org/10.1016/j.tetlet.2008.09.091

46. Sosnovskikh, V. Y.; Moshkin, V. S. Chem. Heterocycl. Chem. 2012, 48, 139-146. http://dx.doi.org/10.1007/s10593-012-0977-3

47. Ghosh, C. K.; Chakraborty, A. Arkivoc 2015, (vi), 417-445. http://dx.doi.org/10.3998/ark.5550190.p009.273

48. Roma, G.; Ermili, A.; Mazzei, M. J. Heterocycl. Chem. 1976, 13, 761-764. http://dx.doi.org/10.1002/jhet.5570130415

49. Raj, T.; Bhatia, R. K.; Sharma R. K.; Gupta, V.; Sharma, D.; Ishar, M. P. S. Eur. J. Med. Chem. 2009, 44, 3209-3216. http://dx.doi.org/10.1016/j.ejmech.2009.03.030

50. Raj, T.; Bhatia, R. K.; Kapur, A.; Sharma, M.; Saxena, A. K.; Ishar, M. P. S. Eur. J. Med. Chem. 2010, 45, 790-794. http://dx.doi.org/10.1016/j.ejmech.2009.11.001

51. Duda, B.; Tverdomed, S. N.; Röschenthaler, G.-V. Org. Biomol. Chem. 2011, 9, 82288232.

http://dx.doi.org/10.1039/C1OB06379K

52. Esmaeili, A. A.; Ghareghani, O. Helv. Chim. Acta 2007, 90, 1712-1717. http://dx.doi.org/10.1002/hlca.200790178

53. Yoon, K.; Ha, S. M.; Kim, K. J. Org. Chem. 2005, 70, 5741-5744. http://dx.doi.org/10.1021/jo050420c

54. Ghosh, C. K. Synth. Commun. 1978, 8, 487-490. http://dx.doi.org/10.1080/00397917808063577

55. Ghosh, C. K.; SinhaRoy, D. K.; Mukherjee, K. K. J. Chem. Soc. Perkin Trans. 1 1979, 1964-1968. 
http://dx.doi.org/10.1039/P19790001964

56. Abdel-Rahman, A.-R. H.; Girges, M. M.; El-Ahl, A.-A. S.; Sallam, L. M. Heteroatom Chem. 2006, 17, 2-7.

http://dx.doi.org/10.1002/hc.20152

57. Ibrahim, S. S.; Allimony, H. A.; Abdel-Halim, A. M.; Ibrahim, M. A. Arkivoc 2009, (xiv), $28-38$.

http://dx.doi.org/10.3998/ark.5550190.0010.e03

58. Ibrahim, M. A.; El-Gohary, N. M.; Ibrahim, S. S.; Said, S. Chem. Heterocycl. Compds. 2015, 50, 1624-1633.

http://dx.doi.org/10.1007/s10593-014-1632-y

59. Ryabukhin, S. V.; Plaskon, A. S.; Naumchik, V. S.; Volochnyuk, D. M.; Pipko, S. E.; Tolmachev, A. A. Heterocycles 2007, 71, 2397-2411.

http://dx.doi.org/10.3987/COM-07-11128

60. Parveen, M.; Malla, A. M.; Alam, M.; Ahmad, M.; Rafiq, S. New J. Chem. 2014, 38, $1655-$ 1667.

http://dx.doi.org/10.1039/C3NJ01384G

61. Ibrahim, M. A. Tetrahedron 2013, 69, 6861-6865.

http://dx.doi.org/10.1016/j.tet.2013.06.011

62. Ibrahim, M. A.; Hassanin, H. M.; Gabr, Y. A.; Alnamer, Y. A. J. Braz. Chem. Soc. 2012, 23, 905-912.

http://dx.doi.org/10.1590/S0103-50532012000500016

63. Ibrahim, M. A.; Hassanin, H. M.; Gabr, Y. A.-A.; Alnamer, Y. A.-S. Eur. J. Chem. 2010, 1, 195-199.

http://dx.doi.org/10.5155/eurjchem.1.3.195-199.91

64. Siddiqui, Z. N. Tetrahedron Lett. 2012, 53, 4974-4978.

http://dx.doi.org/10.1016/j.tetlet.2012.07.013

65. Eiden, F.; Berndl, K. Arch. Pharm. (Weinheim) 1986, 319, 347-354.

http://dx.doi.org/10.1002/ardp.19863190410

66. Maiti, S.; Panja, S. K.; Bandyopadhyay, C. J. Heterocycl. Chem. 2010, 47, 973-981. http://dx.doi.org/10.1002/jhet.397

67. Roma, G.; Di Braccio, M.; Ermilli, A. Farmaco, Ed. Sci. 1979, 34, 646-656.

68. Singh, G.; Singh, G.; Ishar, M. P. S. Helv. Chim. Acta 2003, 86, 169-180. http://dx.doi.org/10.1002/hlca.200390008

69. Ali, E.-S. T.; Abdel-Azi, A.-A. S.; El-Shaaer, H. M.; Hanafty, F. I.; El-Fauomy, A. Z. Turkish J. Chem. 2008, 32, 365-374.

http://journals.tubitak.gov.tr/chem/issues/kim-08-32-3/kim-32-3-9-0711-15.pdf

70. Parveen, M.; Azaz, S.; Malla, A. M.; Ahmad, F.; Ahmad, M.; Gupta, M. RSC Adv. 2016, 6, 148-162.

http://dx.doi.org/10.1039/C5RA21146H

71. Waldmann, H.; Karunakar, G. V.; Kumar, K. Org. Lett. 2008, 10, 2159-2162. 
http://dx.doi.org/10.1021/o18005634

72. Ibrahim, M. A. Synth. Commun. 2009, 39, 3527-3545.

http://dx.doi.org/10.1080/00397910902788141

73. Ibrahim, M. A. M. Eur. J. Chem. 2010, 124-128.

http://dx.doi.org/10.5155/eurjchem.1.2.124-128.75

74. Dormer, P. G.; Eng, K. K.; Farr, R. N.; Humphrey, G. R.; McWilliams, J. C.; Reider, P. J.; Sager, J. W.; Volante, R. P. J. Org. Chem. 2003, 68, 467-477.

http://dx.doi.org/10.1021/jo026203i

75. Nagarajan, S.; Arjun, P.; Raaman, N.; Das, T. M. Carbohydr. Res. 2010, 345, 1988-1997. http://dx.doi.org/10.1016/j.carres.2010.07.016

76. Siddiqui, Z. N.; Khuwaja, G.; Asad, M. Indian J. Chem. 2006, 45B, 2341-2345. http://nopr.niscair.res.in/bitstream/123456789/6691/1/IJCB\%2045B(10)\%202341-2345.pdf

77. Siddiqui, Z. N.; Praveen, S.; Farooq, F. Chem. Papers 2010, 64, 818-824. http://dx.doi.org/10.2478/s11696-010-0072-0

78. Dusemund, J.; Schurreit, T. Arch. Pharm. (Weinheim) 1984, 317, 377-379. http://dx.doi.org/10.1002/ardp.19843170419

79. Schurreit, T. Arch. Pharm. (Weinheim) 1987, 320, 500-506. http://dx.doi.org/10.1002/ardp.19873200605

80. Ellis, G. P.; Romney-Alexander, T. M. J. Chem. Res. (S) 1984, 350-351.

81. Ibrahim, M. A.; El-Gohary, N. M.; Said, S. J. Heterocycl. Chem. 2016, 53, 117-120. http://dx.doi.org/10.1002/jhet.2285

82. Maiti, S.; Panja, S. K.; Bandyopadhyay, C. Tetrahedron Lett. 2009, 50, 3966-3969. http://dx.doi.org/10.1016/j.tetlet.2009.04.087

83. Maiti, S.; Panja, S. K.; Bandyopadhyay, C. Tetrahedron Lett. 2011, 52, 1946-1948. http://dx.doi.org/10.1016/j.tetlet.2011.02.053

84. Maiti, S.; Mallick, S.; Panja, S. K.; Pal, C.; Bandyopadhyay, C. Synlett 2011, 2001-2004. http://dx.doi.org/10.1055/s-0030-1260977

85. Maiti, S.; Panja, S. K.; Sadhukhan, K.; Ghosh, J.; Bandyopadhyay, C. Tetrahedron Lett. 2012, 53, 694-696.

http://dx.doi.org/10.1016/j.tetlet.2011.11.130

86. Maiti, S.; Lakshmykanth, T. M.; Panja, S. K.; Mukhopadhyay, R.; Datta, A.; Bandyopadhyay, C. J. Heterocycl. Chem. 2011, 48, 763-768.

http://dx.doi.org/10.1002/jhet.567

87. Singh, G.; Ishar, M. P. S.; Gupta, V.; Singh, G.; Kalyan, M.; Bhella, S. S. Tetrahedron 2007, 63, 4773-4778. http://dx.doi.org/10.1016/j.tet.2007.03.086

88. Singh, S.; Chopra, A.; Singh, G.; Saxena, A. K.; Ishar, M. P. S. J. Pharm. Res. 2013, 7, 337-341.

http://dx.doi.org/10.1016/j.jopr.2013.04.018 
89. Biswas, P.; Ghosh, J.; Maiti, S.; Banerjee, S.; Bandyopadhyay, C. Tetrahedron Lett. 2013, 54, 3466-3470.

http://dx.doi.org/10.1016/j.tetlet.2013.04.095

90. Singh, B.; Sharma, V.; Singh, G.; Kumar, R.; Arora, S.; Ishar, M. P. S. Internat. J. Med. Chem. 2013, Article ID 984329, 7 pages.

http://dx.doi.org/10.1155/2013/984329

91. Maiti, S.; Panja, S. K.; Bandyopadhyay, C. Tetrahedron 2010, 66, 7625-7632.

http://dx.doi.org/10.1016/j.tet.2010.07.028

92. Maiti, S.; Biswas, P.; Ghosh, J.; Drew, M. G. B.; Bandyopadhyay, C. Tetrahedron 2014, 70, 334-339.

http://dx.doi.org/10.1016/j.tet.2013.11.062

93. Biswas, P.; Ghosh, J.; Maiti, S.; Bandyopadhyay, C. Tetrahedron Lett. 2014, 55, 68826886.

http://dx.doi.org/10.1016/j.tetlet.2014.10.095

\section{Authors' Biographies}

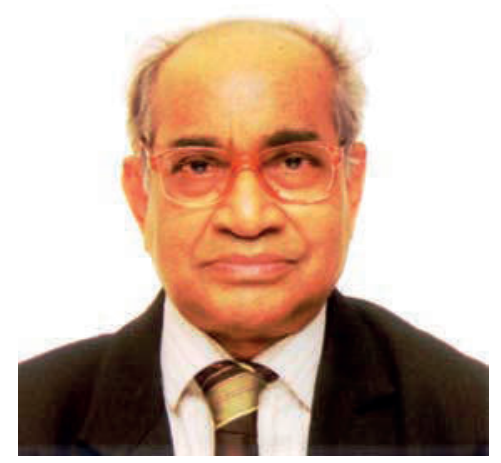

From the University of Calcutta Chandra Kanta Ghosh took his M.Sc., Ph.D. and D.Sc. degrees in Chemistry in 1965, 1970 and 1996, respectively. He did his postdoctoral research in the Department of Organic Chemistry, Karlsruhe University, Germany (1973-74) and in the Biology Division of Oak Ridge National Laboratory, USA (1979-80). He was a faculty member in Organic Chemistry Section in the Department of Biochemistry, Calcutta University during 1969-2007. Even after his formal retirement as a Professor in 2007, Dr. Ghosh has contributed to many journals. His research interest lies mainly in the chemistry of 1-benzopyran-4-one (chromone) having an electron withdrawing group at its 3-position. He has so far sixty seven publications in this field. 


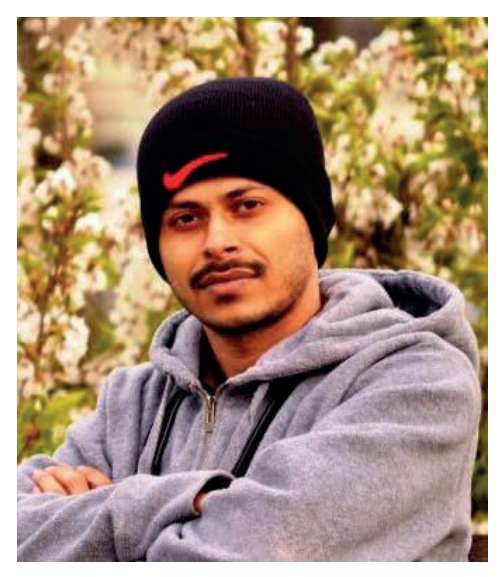

Amarnath Chakraborty received his B.Sc. and M.Sc. in Chemistry from Vidyasagar University, India in 2002 and 2004 respectively. After obtaining Ph.D. in 2011 for his work on organometallic chemistry with Professor Amitabha Sarkar in Indian Association for the Cultivation of Science (IACS), Kolkata, he moved to Radboud University, Netherlands for his postdoctoral research with Professor Jan C. M. van Hest. Then he joined the laboratory of Professor Amitabha Sarkar as a Research Associate in the Department of Organic Chemistry at IACS, Kolkata. Currently he is an Assistant Professor at the Department of Basic Sciences and Humanities in the Institute of Engineering \& Management (IEM), Salt Lake, Kolkata, India. His current research interest is focused on synthetic organic and organometallic chemistry as well as the synthesis of novel heterocycles from 1-benzopyran-4-ones.

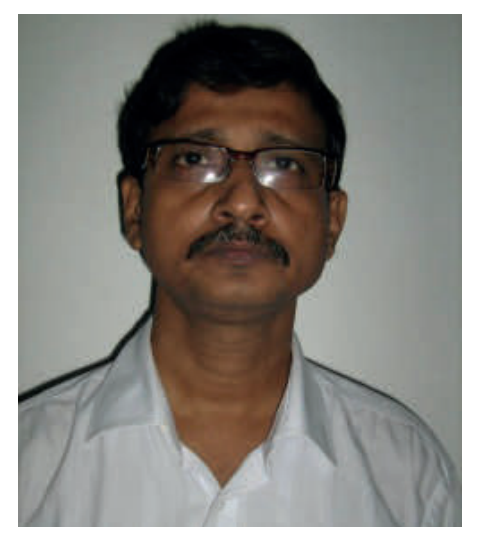

Chandrakanta Bandyopadhyay received his B. Sc., M. Sc. and Ph. D. degrees in Chemistry from the University of Calcutta in 1978, 1980 and 1987, respectively. He worked under the supervision of Prof. C. K. Ghosh for his doctoral degree. He joined the Department of Chemistry, Ramakrishna Mission Vivekananda Centenary College, Kolkata as a junior Lecturer in the year 1984. At present he is working as the Head of that department. He did his postdoctoral research in the Department of Chemistry, Academia Sinica, Nankang, Taipei in 1991 with Prof. Ruben J. R. Hwu. His independent research interest lies on the chemistry of chromones, bichromones and bischromones, and multicomponent reactions based on chromone skeleton. He has so far fifty publications with principal authorship in this field. He has been 
honored with Prof. Navneeth Rao Best Teacher Award in 2013 by A. V. Rama Rao Research Foundation, Hyderabad and Coastal Chemical Research Society Award (Category C) in 2015. 